\title{
İSLAM TASAVVUFUNDA HİNT TESİRİ İDDİALARI ÜZERINE BİR İNCELEME
}

\author{
A Study On Claims Of Indian Influence In The Islamic Sufism
}

Dr. Necdet AYHAN

Milli Eğitim Bakanlı̆̆ı, Tokat, Türkiye,necdetayhan1@hotmail.com

\begin{tabular}{|c|c|}
\hline & $\ddot{\mathbf{O ̈ z}}$ \\
\hline Makale Bilgisi & $\begin{array}{l}\text { Bilindiği üzere İslam dininin Allah'ın vahyi ile teşekkül ettiği ilk dönemde İslam tasavvufunun özünü } \\
\text { oluşturan zühd hayatıyla ilişkili ayet ve hadislerde temel kavramlar bulunmasına rağmen "sûfî ve }\end{array}$ \\
\hline Geliş/Received: & tasavvuf" kelimeleri henüz yoktu. Ancak İslam'ın ilk döneminde bu kelimelerin kaynağı olarak kabul \\
\hline 17.08 .2021 & $\begin{array}{l}\text { gören suffe ashabı veya suf denilen yün elbise giyenlerin varlığı ise bir gerçektir. Bu bağlamda } \\
\text { tasavvufun Kur'an ve hadislere dayalı veya naslarla oluşan geleneklere dayalı bir ilim mi, yoksa Hint }\end{array}$ \\
\hline Kabul/Accepted: & mistisizmi gibi yabancı kaynaklardan etkilenerek oluşan bir ilim mi olduğu tartışması gündeme gelmiştir. \\
\hline Sayfa/ Page: & görülmektedir. Son zamanlarda Türkiye'de İslam tasavvufu alanında Britanya oryantalizminin yanı sıra \\
\hline $177-198$ & $\begin{array}{l}\text { Alman ekolü veya akademik oryantalizm üzerine gerçekleştirilen yeni akademik araştırmalar, bahse konu } \\
\text { iddiaların tekrar irdelenmesini gerekli kılmıştır. Bu makalede, İslam tasavvufuna Hint asıllı yabancı } \\
\text { köken arama girişimlerinin birincil ve ikincil kaynakları incelenmektedir. İslam tasavvufunu etkilediği } \\
\text { iddia edilen yabancı kaynaklardan Hindistan'da Müslüman devlet yönetimindeki Hint mistisizminin } \\
\text { İslam ile kültürel etkilesiminin içeriği ve tarihcesi ilmî veriler ıs̆ı̆̊nda değerlendirilmektedir. }\end{array}$ \\
\hline
\end{tabular}

Anahtar Kelimeler: Tasavvuf, Hint Mistisizmi, Oryantalist, Kültürel Etkileşim, Siyasi veya Bilimsel Amaçlı İddialar.

\begin{abstract}
As it is known, the words "sufi and sufism" did not exist yet, although there were basic concepts in the verses and hadiths related to the life of asceticism (zuhd), which formed the essence of Islamic sufism, in the first period when the religion of Islam was formed by the revelation of Allah. However, the existence of the companions of the suffa, who were accepted as the source of the words "suf" and "suffa" in the first period of Islam, and those who wore woolen clothes called suf, is a fact. In this context, the debate has come to the fore whether sufism is a science-based on the Qur'an and hadiths or Islamic traditions, or a science influenced by foreign sources such as Indian mysticism. In the studies conducted in the field of Islamic sufism, it has been observed whether the scientific evidence on which the criticisms presented by foreigners are based, especially on the Indian influence on Islam, are not considered one by one in a single study. Recently, in Turkey new academic researches carried out on the German school or academic orientalism as well as British orientalism in the field of Islamic sufism necessitated the examination of the aforementioned claims again. In this article, primary and secondary sources of attempts to search for Indian origins in Islamic sufism are examined. The content and history of the cultural interaction of Indian mysticism with Islam in the Muslim state administration in India, from foreign sources that are claimed to have influenced Islamic sufism, are evaluated in the light of scientific data.
\end{abstract}

Keywords: Sufism, Hint Mysticism, Orientalist, Cultural Interaction, Political or Scientific Claims.

Atıf/Citation: AYHAN, N. (2021). İslam Tasavvufunda Hint Tesiri İddiaları Üzerine Bir İnceleme. MECMUA - Uluslararası Sosyal Bilimler Dergisi ISSN: 2587-1811 Y1l: 6, Say1: 12, Sayfa: 177-198.

Sorumlu Yazar/Corresponding Author: Dr. Necdet AYHAN

Çatışma Beyanı/Conflict Statement: Makalenin yazarı/yazarları bu çalışma ile ilgili taraf olabilecek herhangi bir kişi ya da finansal ilişkileri bulunmadığını dolayısıyla herhangi bir çıkar çatışmasının olmadığını beyan eder/ederler. 


\section{Giriş}

Tasavvufî yaşantının temeli olarak inanan insanın duygu dünyasında yaratanıyla ilahi iletişimin algı boyutunu kapsayan duygusal tecrübesi dayanak olarak alınırsa, vahye muhatap olan Peygamberlerin yaşadığı boyutun bir veya birkaç boyut altında nefsini dünya bağlarından arındırabilen ve Hakk'ın tecellilerini müşahede edebilen inançlı Müslümanlara da maneviyatta ilham ve keşif yoluyla ruhani miraç kapısı açık olmalıdır. Bu durum inanan bireyin dini tecrübesini daha da anlamlı hâle getirmektedir.

Hicrî üçüncü ve dördüncü asırlarda tarihî Türkistan bölgesi Budizm manastırlarının yaygınlığıyla ünlenmiştir. Bu coğrafyanın parçası olan Bistâm ve Belh kentini de içine alan Horasan bölgesinde yetişen Bâyezîd-i Bistâmî ve Şakîk-i Belhî gibi bazı ilk dönem sûfîlerin Hinduizm ve Budizm mistik anlayışından etkilendikleri iddia edilmiştir. Bu iddia İslam tasavvufuna ilgi duyanları ve hatta İslam tasavvufuna gönülden bağlı olanları tereddüt ve kafa karışıklığı içerisinde bırakarak İslam kültürünün yetersizliklerinin bulunduğu kaygısını uyandırma, böylece İslam tasavvufunu diğer dinlerin mistik anlayışları karşısında zayıf duruma düşürme çabası olarak anlaşılmıştır.

Yaşanılan hayata anlam kazandıran evrensel ve insani değerlerin dünya genelindeki çoğu inançlarda ortak olarak bulunması nedeniyle tasavvufî veya mistik tecrübe konusundaki bu incelememiz, karşılaştırmalı metin içeriği ve kavramlara dayalı veri analizi şeklinde olmayıp alan incelemesinden oluşmaktadır. Daha çok İslam dinine mensup olmayanlarca gündeme getirilen bahse konu iddialar hakkında yapılan yorumlarla yetinilmeyip bizzat iddianın birincil kaynağındaki orijinal metni ve ikincil kaynaklardaki değerlendirmeleri paylaşma şeklinde İslam dinine mensup günümüz tasavvuf araştırmacısının ilmî veriler kapsamında ilim ahlakıyla yaklaşımı bağlamında incelenmektedir. Birincil ve ikincil kaynaklar konusundaki ayrıntılar, çalışmanın hacmini aşacağından ilgili konu içerisinde bir kısmının sadece isimlerine değinilerek kısıtlamaya gidilmiştir. Bahse konu iddialarda geçen ve zaman içerisinde netlik kazanmayan, birbirleriyle çelişen görüşlere dikkat çekilip cevaplar aramaya odaklanılmıştır.

Birincil ve ikincil kaynaklarda geçen İslam tasavvufuna Hint tesiri iddialarının tarihçesi, ilk savunucuları, bahse konu iddialara sebebiyet veren bazı tarihi olaylar ve kimi İslam âlimlerinin bu konuyla ilgili ilmî verilere değil zanna dayalı olumsuz yorumları, Hindistan'daki Müslüman devlet başkanı Ekber Şah'ın (ö. 1014/1605) siyasi güç edinme adına Hint kültürünü etkileme çabaları, İslam ve Hint kültürünün etkileşim boyutu irdelenmektedir. Bu bağlamda İslam'ın Hint kültüründen etkilendiği iddiasına örnek olarak sunulan Şakîk-i Belhî (ö. 194/810) menkıbesi, İbrahim b. Edhem'in (ö. 161/778?) hayat hikayesiyle Buda'nın (m.ö. 483) yaşantısının benzerliği, Bâyezîd-i Bistâmı̂’nin (ö. 234/848?) nefes hapsiyle Allah'1 zikretme yönteminin yoga nefes kontrolüne benzetilmesi, sûfîler tarafından geleneksel tasavvufî meditasyon (seyr ü sülûk ve riyazet) sürecinde dikkate alınan manevi latâif (kalp, ruh, sır, hafi, ahfa latifeleri) olgusunun, Allah'ın doksan dokuz isminden müteşekkil zikir formüllerinin ve zikirde nefes kontrolünün (zikr-i erre vb.) yogadaki çakra fizyolojisi ve mantraların (zihinsel arınma yöntemlerinin) kuvvet boyutlarını ihtiva eden yoga öğretilerine benzetilmesi değerlendirilmektedir. İslam tasavvufunda tecrübe ile yaşanılan fenâ hâlinin nirvanaya benzetilmesi, İslam topraklarında yaşayan kimi Kalenderî dervişlerin Budist ve Maniheist rahiplere benzetilmesi, kimi İslam âlimlerinin bazı tasavvufî kavramları Hint mistisizminde yer alan kavramlara benzetmeleri gibi iddiaların ilmî dayanakları incelenmektedir.

\section{1. İslam Tasavvufunda Hint Tesiri İddialarının Tarihçesi ve İlk Savunucuları}

İslam dini dört halife döneminde ve devamında Hindistan topraklarında ilk olarak öncü akınlarla Arap ve Afgan kökenli Müslüman devlet yöneticileri tarafından yayılmaya başlamıştır. Delhi Türk Sultanlarının ülke yönetimine hâkim olduğu 1206 yılından sonra daha büyük bölgelerde etkin olarak 
yayılmaya devam etmiştir. İslam tasavvufunun yabancı kaynaklı olduğu iddiası ise, İslam'ın Hindistan serüveninden yüz yıllar sonra on sekizinci yüzyılın ikinci yarısında ortaya çıkmıştır. İslam tasavvufunun Hint tesiri ile şekillendiğini tarihte ilk defa iddia eden kişi İngiliz oryantalist Sir William Jones'dur (ö. 1794). Onu Alman Protestan Teolog Friedrich August Gottreu Tholuck (ö. 1877) takip etmiştir. Alfred Von Kremer (ö. 1889) daha çok Geschichte der herrschenden Ideen des Islams: der Gottesbegriff, die Prophetie und Staatsidee (İslam'ın egemen fikirlerinin tarihi: Tanrı kavramı, peygamberlik ve devlet fikri) adlı kitabında tasavvufun çileci ve panteist yönü eleştirisini yapmıştır. Ignáce/Ignaz Goldziher (ö. 1921), Max Horten (1874-1945), Richard Hartmann (ö. 1965) ve Robert Charles Zaehner (ö. 1974) onları takip etmiştir (Ülken, 1995, s. 139).

Oryantalistlerin iddialaryyla aynı olmasa da Hint mistisizmiyle İslam tasavvufundaki kavram benzerlikleri bazı İslam bilginleri tarafından da dile getirilmiştir. Mesûdî (ö. 345/956) Mürûcu'zZeheb'inde ve Bîrûnî (ö. 440/1048) Tahkîku mâ li'l-Hind'inde bu konudaki görüsslerini yazmışlardır. Ancak bu İslam bilginlerinin eleştirileri konuyu ayrıntılı olarak ele almaya dayalı olmayıp sathî malumatla tasavvufî kavramlardan bazılarının, Hint mistik düşüncesinde yer alan bazı kavramlara benzerliğine yönelik ihtimaller üzerine polemik niteliğinden öteye geçmeyen şahsi görüşlerdir (Çift, 2007a, 2007b; Yaman, 2013, ss. 23, 25). Her ne kadar sûfî ve tasavvuf kelimelerinin İslam'in ilk döneminde varlığı tartışmalı olsa da (Ayrıntı için bk. Akdağ, 2019) asr-1 saadette zühd hayatı olarak var olduğu hâlde günümüzdeki ismi o dönemde henüz konulmamış tasavvuf ilmi gibi bazı İslami ilimler de İslam kaynaklarından doğmuş olup menşei Kur'an ve sünnettir. Çünkü İslam kültürünün dayandığı naslar pek çok kaynağı besleyecek yeterliliğe ve imkâna sahiptir. İslam medeniyetinin kültürel zenginliği, yabancı kaynaklara muhtaç olmayacak kadar yetkindir. $\mathrm{Bu}$ nedenle İslam tasavvufu da Kur'an ve sünnette var olan zühd ve nefis mücahedesi anlayışıyla ortaya çıkmıştır. İslam tasavvufundaki bazı uygulamaların yabancı mistik anlayışlarla benzerliklere sahip olduğu görüşü ise, ilk önce Mesûdî, Bîrûnî, İbn Teymiyye ve taraftarları gibi kimi İslam âlimlerince de ileri sürülmüştür.

William Jones sonrasında devam ettirilen söz konusu iddialar kapsamında Hindistanlı Aziz Ahmed, İbnü'l-Arabi'nin (ö. 638/1240) özellikle Fusûs'unda geçen, evrendeki her varlığın hakikatte Yüce Allah'ın nurunun yansıması yani tecellisi olduğu anlayışıyla, İngiliz antropolog Edward Burnett Tylor (ö. 1917) tarafından "Primitive Culture" adlı kitabında ileri sürülen canlandırmacıllı (animizm) ve Hindu çok tanrıcılığını çağrıştıran görüş arasındaki benzerlikten bahseder. Yine İbnü’l-Arabi’nin ilahi aşk konusunda kutsal olanı insani ve süfli boyuta indirgemeye dönüştürmesinin Hinduizm'in dini eserlerinden birisi olan Upanişaddaki Tanrı Brahman'ın insan olan sevgilisiyle ilişkilendirilen benzetmenin o dönemde Hindistan'da nüfuz kazanmaya çalışan İbn Teymiyye (ö. 728/1328) yanlılarınca istismar konusu edilerek kullanıldığına dikkat çeker. Halbuki Allah, mutlak zatıyla evrenden aşkınken panteizm, hulûl ve ittihattan uzak bir şekilde ilahi isimlerinin çok farklı tecellileriyle evrende içkindir. Bir başka ifadeyle Allah'ın mutlak zatı, evrendeki tecelliler ile ilişkilidir ancak evrenin içinde değildir. Yukarıdaki örnekte Brahman'a atfedilen ilahın mutlak zatı ile evrende içkin olması, İslam tevhid inancında yoktur. Bu durum ise vahdet-i vücûd anlayışının temeliyle bağdaşmayan zit bir görüştür. Hindistanlı Müslüman akademisyen Aziz Ahmed de (ö. 1962) Tylor'ın iddialarını benzer şekilde eleştirdikten sonra Ahmed es-Sirhindî’ye (ö. 1034/1624) ait mutlak varlık olarak birliğin tecellisini arifin gözlemiyle varlıklarda görebilme (vahdet-i şühûd) öğretisinin asıl fikir babasının Madhva (ö. 1276) adıyla tanınan bir şahıs olduğundan ve Ahmed es-Sirhindî'den yaklaşık dört yüz yıl önce Hint mistik düşüncesinde bu görüşe benzer bir öğreti oluşturduğundan söz edenlerden bahseder. Ancak Aziz Ahmed vahdet-i şühûdun, Hint felsefesindeki mistik anlayışta kökeninin bulunduğu görüşünü reddederek Ahmed es-Sirhindî’nin on yedinci yüzyıl Hindistan İslam düşüncesinde yer alan tartışmalarla vahdet-i şühûd görüşünü ortaya koyduğunu, Madhva isimli Hint mistiğin öğretisinden etkilenmediğini, hatta kendi öğretisinin daha önceki versiyonundan Ahmed esSirhindî’nin haberinin olmadığını değerlendirmektedir. Hatta Madhva'nın dünyayı var edici asıl neden 
olarak Allah'1 kabul etmemesi, iki öğretinin zaten temelde birbirinden ayrı olduğunu göstermektedir (Ahmed, 1964, s. 127).

\section{Hint Tesiri İddialarma Sebebiyet Veren Bazı Tarihi Olaylar}

Bahse konu iddiaların kaynağını besleyen iki tarihi olay, daha belirgin şekilde öne çıkmaktadır. Birincisi; Hindistan'ın Müslüman devlet başkanı Ekber Şah ve Prens Dârâ Şükûh'un Hint dini metinleri üzerine yaptıkları çalışmalardır. İkinci tarihi olay ise, İslam tasavvufundaki Hint tesirini tarihte ilk defa İngiliz oryantalist Sir William Jones'un ileri sürmesiyle ortaya çıkan faaliyettir.

Hindistan'da Müslüman Bâbür devlet başkanı Ekber Şah'ın, İslam ile Hint dinlerini yakınlaştırmak için "Allah-Upanişad" kutsal kitabını yazdırmasıyla başlayıp daha sonra Dârâ Şükûh (ö. 1069/1659) adlı şehzadenin 1657 yılında Upanişadların elli bölümünü Farsçaya tercüme ettirmesiyle devam ettirilen faaliyetler kültürel etkileşimde önem arz etmektedir. Dara-Şükûh, kutsal saydığı bu eserleri Kur'an'ın Vâkıa suresi yetmiş sekizinci ayetindeki “Gerçekten Kur'an gizli bir kitaptadır” ilahi ifadesiyle ilişkilendirmektedir (Bayur, 1987, s. 1/34). Ekber Şah, muhtemelen Hindularla Müslümanlar arasındaki çatışmalara son vermek niyetiyle İslâmiyet ile özellikle Hindistan'da halkın büyük kesiminin inancını oluşturan Hinduizm, Budizm gibi inanç sistemlerinin evrensel ortak değerler olarak kabul edilen prensiplerini birleştirerek "ilahi din" adıyla yeni ortak bir din kurmuştur (Konukçu, 1994). Bu yeni dinin Hinduizm uzantısı, Upanişadlardaki her şeyin Tanrı'da saklı olduğu (Kaya, 2014; Müller ve Deussen, 2010) gibi vahdet-i vücûd inancını çağrıştıran düşüncelere dayandırılmıştır. Böylece mevcut Müslüman devlet yönetiminin siyasa gütme (Bayur, 1987, s. 1/34) yani dini siyasete alet etme planı söz konusu olmuştur. Kanaatimize göre bu durumda, siyasetin genel anlamda yetkisini aşacak şekilde dine müdahalesinde özel anlamda İslam dini aktif, Hinduizm ile Budizm ise pasif durumdaydı. Yani yüz yıllar süren Türk ve Müslüman devlet yönetiminin hakimiyeti altındaki Hindistan'da İslam tasavvufunun, Hint mistisizminden etkilenmesi imkân dahilinde değildi. Anladığımız kadarıyla Ekber Şah döneminde evrensel ortak değerlerden yararlanılarak Hinduizm dini metinlerinin içerisine, İslam dini metinlerinin serpiştirilmesi sonucunda Hinduizm ve Budizmi etkileme düşüncesi amaçlanmıştır. Bu yapılan doğru mu yanlış $m ı$ tartışmaya açık bir konudur.

Sanskrit dilinde yazılmış Upanişadlara ilave olarak Hinduizm kutsal kitabı Vedalar ve Hint mistisizminin diğer temel eserlerinden olan ve İslam tasavvufunu etkilediği iddia edilen kaynaklardan Ramayana Maha-Barata (Valmiki, 1975), yine Maha-Barata'nın içinde bulunan "Bagavat-Gita" (Bhagavadgita) yani "Kutsal kişi tarafindan söylenen türkü" ve Upanişadlar konusunda Bayur ayrıntı vermektedir (Bayur, 1987, s. 1/116-117). Ekber Şah yeni din sayesinde Hintlilerce en çok okunan eserler aracılı̆̆ıyla Brahman zihniyetin yabancı inançlara tepkisini ve tesirini kırmış, geleceğe yönelik siyasi istikrar ve devlet güvenliğini sağlamış olacaktı.

Bahse konu iddiaya sebep olan ikinci tarihi olay ise şöyledir: Sir William Jones, Mevlânâ Celâleddîn-i Rûmî ve Hâfız-1 Şîrâzî gibi Müslümanların şiirleri ile Bagavat-Gita (Bhagavadgita) metinleri arasındaki benzerliğin çok dikkat çektiğini iddia etmiştir. Jones’un bu iddiayı ileri sürdüğü dönemin öncesinde, Müslüman Bengal'in yönetimi 1757 yılında tamamen İngilizlerin eline geçmişti (Özcan, 1998, s. 78). Yani Müslüman ülkelerin İngiliz yönetimleri tarafından işgali ile İslam tasavvufunun zayıf ve yetersizliği, hatta yabancı tesir olmadan ayakta duramayacağı konusunda yapılan ilmî çalışmalar arasında paralellik görülmektedir. İngilizler, Bengal sonrasında Müslüman Hindistan yönetimini ele geçirmeye Mumbai'den başlayan bir çalışmayla Hindistan'da da Britanya egemenliğine hazırlanıyordu (Kopf, 1969). Aşamalı bir şekilde sürerek devam eden İslam tasavvufu araştırmalarında Alman ekolü dönemi ya da "akademik oryantalizm dönemi" denilen faaliyetler, İslâm dininin Hıristiyanlıktan yetersiz olduğunu empoze etme amacına hizmet eden ve bilimsel gibi gösterilen siyasi faaliyetlerdir. Oryantalizmde "Alman Ekolü" ifadesiyle kastedilen, eserlerini Almanca kaleme alan Almanya, Avusturya, Polonya, Macaristan, İsviçre vb. gibi ülkelerde 
tasavvuf üzerine araştırmalar yapan müsteşriklerin tamamıdır (Çift, 2007a). Bu amaçla Alman ve İngiliz oryantalizminin bazen ortak olarak birbirini destekleyici çalışmalarının bulunduğu görülmektedir. Hindistan ile ilgili İslam'a Hint tesiri iddialarını üreterek güneyde bölgenin en büyük ticaret merkezi olan Mumbai kentinden başlayıp zamanla tüm Hindistan'a egemen olmaya çalş̧an İngiliz Doğu Hindistan Şirketi’nin siyasi gücüne Britanya oryantalizminin akademik destek verdiği bir gerçektir. Örneğin August Tholuck olarak tanınan Polonya kökenli Alman Protestan kilisesi teoloğu Friedrich August Gottreu Tholuck (ö. 1877) ve Avusturyalı oryantalist Alfred Von Kremer (ö. 1889) daha yakın zamanda da Macar asıllı Mûsevî müsteşrik Ignác Isaac Jehuda Goldziher (ö. 1921) İslam’a Hint tesiri fikrini devam ettirmeye çalışmışlardır. Ancak Hilmi Ziya Ülken, söz konusu müsteşriklerin savundukları iddiaların kuvvetli delillere dayanmadığını belirttikten sonra tersine olarak Hint kültürü üzerinde İslam'ın etkisinin daha çok ve daha açık olduğunu vurgular. Bu görüşüne delil olarak Türk ve Fars mutasavvıfları ile Karmatîlerin Hindistan'da İslam fikrini, Hint tesiri iddialarından çok daha önce yaydıklarını ifade eder. Ayrıca İngiliz oryantalizm çalışmalarının Sir William Jones'la başlaması (Ülken, 1995, s. 139) ve bazı İngiliz oryantalistlerin iddialarının (Derin, 2018) aksine Hilmi Ziya Ülken'in Hint kültürü üzerinde İslam'ın etkisinin daha çok olduğu değerlendirmesi önem arz etmektedir.

İslamiyet Hint topraklarında savaş yoluyla değil de sûfîler tarafindan barışçıl yolla yayılmıştır. (Massignon, 1922, ss. 68-69). On dördüncü yüzyılın başında Keşmir'de sayısı on binlerle ifade edilen Hindu ve Budist halkın, bölge yöneticileriyle birlikte ve kendi rızalarıyla topluca İslam'a girip ihtidâ ettikleri olay, H. Ziya Ülken'in görüşünü destekleyen tarihi bir hakikattir. Keşmir'deki ihtida olay1 şöyle olmuştur: Sühreverdiyye tarikatının Hindistan'daki şeyhlerinden Seyyid Şerefüddin Bülbül Şâh el-Hüseynî el-Keşmirî (ö. 728/1327), Şah Nimetullah Fârisî’nin tasavvufta halifesidir. İstilacı Moğol saldırıları nedeniyle şeyhiyle ve maiyetindeki bin kişiyle beraber Türkistan'dan zorunlu olarak Keşmir'e göç eder. O dönemde Keşmir'in idari yöneticisi olan Rinçana, Budizm inancına mensuptu. Hem Budizm hem de yerli halkın inancı olan Hinduizm'den memnun kalmayan Rinçana'ya Bülbül Şah İslam dinini anlatır. Böylece Rinçana Müslüman olur ve adını Sadreddin olarak değiştirir. Bülbül Şah, rivayetlere göre Vali ile Keşmir halkından on bin kişinin Müslüman olmasına vesile olmuştur. Rinçana adını terk eden Emîr Sadreddin, Bülbül Şah için yaptırdığı hankâha çeşitli vakıf kurumlarını bağlamış, vakıfların zengin gelirleriyle bir aşevi kurulmuştur. Ardından da Keşmir'e ilk camii yaptırılmıştır. Bülbül Şah'ın türbesi bu camiinin yanındadır (Azamat, 1992, ss. 486-487).

\section{3. İslam ve Hint Kültürünün Etkileșim Boyutu}

Tasavvuf ilminin doğduğu ve beslendiği kaynak ile ilişkilendirilen İslam tasavvufuna Hint kökenli yabancı tesir konularında tasavvufî eserlerde geçen iddialar incelenmiştir. Bahse konu iddiaların ileri sürülmeye başlandığı zamandan önce Hindistan'da Orta Çağda yaşamış olan mutasavvıfların yazdıkları eserlerde söz konusu iddiaları doğrular nitelikte verilere rastlanılmamıştır. Şakîk-i Belhî ve Bâyezîd-i Bistâmî gibi mutasavvıfların Hint mistik felsefesinin kimi özelliklerini İslam tasavvufuna dahil ettikleri, tasavvuftaki "fenâ" hâlinin nirvana inancından alındığı, İslam coğrafyasında Budist rahiplere benzeyen Kalenderî dervişlerin kökeninin Hint kaynaklı olduğu, Hint kültüründen olan çakra, yoga ve meditasyon ile tasavvufî ibadetlerin birbirine benzediği gibi Hindistan kökenli bazı iddialar incelenerek iki kültürün etkileşim boyutuna değerlendirmelerle ve çalışmadaki sonuca kadar yapılan tartışmalarla belirginlik kazandırılmaktadır.

\section{Hint Tesirine Örnek Verilen Șakîk-i Belhî Menkıbesi}

Erken dönemde yazılan Kuşeyrî’nin er-Risâle adlı eserinde geçen Şakîk-i Belhî’nin zühd ve tasavvuf yoluna yönelmesini sağlayan menkıbe, İlhanlı tarihçilerinden Zekeriya b. Muhammed elKazvînî'nin (ö. 682/1283) eserinde aynen verilmektedir. Ancak Kuşeyrî'de "Türk" beldesi diye geçen ifadenin, Kazvînî'de "Hind" beldesi şeklinde değiştirilerek verildiği dikkat 
çekmektedir. Kazvînî’nin bu yanlış nakli, Goldziher tarafından İslam'a Hint tesiri olarak ileri sürülerek Şakîk'in bir Budist rahibin mistik görüşünden etkilenmesine delil gösterilir. (Ocak, 1999, s. 6) Aşağıda ayrıntılarıyla incelenecek olan Şakîk menkıbesi hakkında kimi oryantalistlerce öne sürülen iddia, 1898'de yayınlanan Bernard Carra de Vaux'un (ö. 1953), La Légende de Bahîrâ, ou Un moine chrétien auteur du Coran (Bahîrâ efsanesi veya Kur'an yazarı Hıristiyan din adamı) adlı kitabının işlediği konuda görülen İslam'da yabancı tesir iddiası ile benzerlik göstermektedir. Bu kitap Sevgili Peygamberimizin henüz dokuz yaşındayken ticaret için amcası Ebu Talib ile Şam'a gittiğinde görüştüğü Rahip Bahira'dan etkilenerek Kur'an'1 onun yönlendirmesiyle yazdığı iddiası üzerine kurgulanmıştır. İslam dininin kutsal kitabının yabancı tesirle oluştuğu şeklindeki bu zorlama örnek, ilim ahlakının ve tarafsızlığının önüne geçen dini taassubun diğer bir ürünüdür.

Hüseyin b. Mansur el-Hallâc'tan (ö. 309/922) daha erken bir dönemde Türk ülkesine veya Hindistan'a gittiği rivayet edilen sûfîlerden birisi Şakîk-i Belhî'dir. Ebû Nuaym el-Isfahânî'nin (ö. 430/1038) Hrlyetü'l-evliyâ'sında (Isfahânî, 1988, s. 8/59) ve Abdülkerim el-Kuşeyrî'nin (ö. 465/1073) erRisâlesi'nde geçen ve Şakîk'in zühd ve tövbe yolunu tutmasına sebep olarak anlatılan olay kimilerince İslam'a Hint tesirine örnek verilen ve bir Budist rahip ile Şakîk-i Belhî arasında geçen konuşmayı anlatan menkıbedir. Bahse konu menkıbe şöyledir: "Şakîk önceleri tacirdi ve genç yaşlarında ticaret için Türk ülkesine seyahat ederdi. Bir keresinde bir puthaneye (beytü'l-asnâma, Budist mabedine) girer. Orada saç ve sakalı tamamen kesilmiş olan, puta (Buda'ya) hizmet eden bir Budist rahip görür. Rahibin üzerinde erguvani renkte bir elbise vardır. Şakîk, ona: "Seni yaratan (el-Hâlık), hayat veren (el-Hayy), bilgide yetkin olan (el-Alîm), kâdir olan (el-Kâdir) ve sana rızık veren (er-Rezzâk) bir ilâh var, bir puta değil de Ona tapınsan iyi olmaz mı? Sana hiçbir fayda veya zarar vermeyecek olan bu puttan vaz geç!" tarzında öneride bulunur. Buda'ya hizmet eden Budist rahip şu karşıllı̆g 1 verir: "Eğer senin dediğin gibi o bahsettiğin ilah, kendi memleketinde sana rızık vermeye kâdir (er-Rezzâk ve elKâdir) ise neden sen evinde oturmuyorsun da bunca sıkıntılara katlanarak çok uzaklardan buralara kadar gelip ticaret için kendini yoruyorsun?” Bu cevap üzerine yakaza halini yaşayan Şakîk-i Belhî, bu soruyu sorarken yaşadığ1 gaflet uykusundan uyanır ve derhal tasavvuf ve zühd yolunu tutar (Attâr, 1387, ss. 251-252; A. b. H. en-Nisaburî el-Kuşeyrî, 2008, s. 397).

İslam'da Hint etkisi ile ilişkilendirilen Şakîk'in söz konusu menkıbedeki ticari seyahat durumu, Massignon ve Öztürk'ün ulaştığı kanaate göre içerik olarak irşad ve araştırma amaçlı Hallâc'ın Hindistan seyahatlerinden farklıdır. Hallâc'ın, 284-289/898-902 yılları arasında Hindistan'da Mansure, Keşmir ve Multan'a yaptı̆ğ seyahatlerin önemli olduğu bilinmektedir. Hallâc'ın 905 yılında, Sind'e gittiği de nakledilmektedir. Bağdat'ı merkez alırsak, Hallâc beş yılı doğuya, beş yılı da batıya olmak üzere, tam on yıllık bir tebliğ hizmeti yapmıştı. Daha çok camilerde, sınırlı olarak da hangâhlarda vaazlar veriyordu. Hallâc'ın Hint seyahati, diğer seyahatleri gibi bir tebliğ ve irşat seyahati idi (Massignon, 2006, ss. 238-240; Öztürk, 1976, ss. 76-80). Ancak Hallac'in Hindistan seyahatlerinin farklı boyutlarının da bulunduğu değerlendirilmektedir. (Bk. Akdağ, 2020) Hallâc'ın Hindistan seyahatinin amacı her ne kadar tartışmalı olsa da menkıbeden anladığımız kadarıyla Şakîk, önceleri zühd yolunda değilken bir başka ifadeyle benimsediği yaşam tarzı olarak İslam tasavvufunu veya İslam ahlakını örnekliğiyle yansıtmaya çalışan bir misyonu henüz yokken Kuşeyrî’ye göre Türk ülkesine gitmiştir ve gidiş amacı ticarettir denilebilir.

Menkıbede söz edilen Şakîk-i Belhî’nin yaşadığı manevi hâle benzer olarak tövbe makamına yönelen sûfîlerin yaşadıkları ortak duygular konusunda klasik tasavvuf kitaplarında genel açıklamalar bulunmaktadır. Bu kaynakların, İslam'a Hint tesiri iddialarından çok önce yazılmış olmaları önem arz etmektedir. Örneğin Ömer es-Sühreverdî (ö. 632/1234) zühd yoluna girmeden önce kimi sûfilerin yaşadıkları zecr, intibah, teyakkuz, yakaza gibi tövbe öncesinde tecrübe edilen bazı hâller konusundaki görüşlerini şöyle nakleder: "İntibah, kişiyi dince iyi ve doğru olana yönelten hâllerin başında gelir. 
Kul, günahlara duyarsızlığın hükmündeki gaflet uykusundan "intibah" ile uyandığg zaman, bu intibah onu "yakaza" hâline ulaştırır. Kişi yakaza hâline ulaştığı zaman, bu durum "teyakkuz" duygusuna sahip olma basamağında, doğru yola yönelmeye hazır ve istekli olma duygusunu sağlar. Yakaza aşamasına gelen birisi, başka bir yolda olduğunu bilip de doğru yola gitmeyi Hak'tan istediği zaman tövbe kapısına yönelir. Böylece en baştaki zecr ve intibah duygusu teyakkuz hâlinin, teyakkuz duygusu yakaza hâlinin, yakaza duygusu ise zühd ve tasavvuf yolunun başlangıcı olarak kabul edilen tövbe hâlinin yaşanmasını temin eder. Sühreverdî'ye göre yakaza; dine uymayan olumsuz davranışlardan dolayı Allah'ın ahirette vereceği cezadan korkan kimselerin kalbine Allah tarafindan ihsan edilen ve onları tövbe etmeye yönlendiren ilahi bir uyarıcıdır. Yakaza hâli tam olan kişi, bu hâli ile tövbe makamına yükseltilir. İnsanın içinde bulunan ve kötülüklerden uzaklaşmasını tetikleyen duygu olan zecr, intibah, teyakkuz ve yakaza duyguları şeklinde işlevine göre alttan yukarıya doğru aşamalı olarak sıralanan bu hâller, kimi sûfillerde tövbeden önce yaşanan manevi hâllerdir. Tövbenin sağlam ve tam olması, kişinin olumsuz davranışlarını düzeltme konusunda iyi bir muhasebe yapmasına muhtaçtır. Zira tövbe ancak kâmil bir muhasebe ile tam ve sağlam olur" (Sühreverdî, 1990, s. 594 vd, 1999, s. 277 vd). Yakaza hâlinin, Allah için ayağa kalkmak, gaflet uykusundan uyanmak ve fetret vartasından sıyrılmak gibi anlamları da vardır (el-Herevî, 2008, s. 75).

Sühreverdî'nin naklinden edindiğimiz izlenime göre Kuşeyrî’nin eserindeki bahse konu rivayet, Şakîk'in İslam tasavvufunu anlatan bir sûfî olarak Hindistan'a gitmesi ile ilgili değildir. Yine aynı menkıbenin bize verdiği bilgiye göre Hindistan gezisinde Şakîk, Budist rahibin sözünden etkilendiği bu olay üzerine tövbe edip zühd ve tasavvuf yoluna girmiştir. Bu tarz gafletten uyanmada "zecr, intibah, teyakkuz"; yakaza hâline ön hazırlık aşamalarıdır. Bu hâller, dini hassasiyetleri hayat felsefesinin merkezine alan yaşam tarzına (zühd yoluna) yönelmeye sebep olan özel manevi bir durumu belirtir. Bahse konu hâllere örnekler tasavvuf konulu menâkıbnâme ve sûfî tabakat kitaplarında geçmektedir. Zühd yoluna girmeye sebep olan bir olay esnasında yaşanan yakaza hâli, dince daha olumlu yeni bir yaşam tarzını seçme konusunda harekete geçirici ve anladığımız kadarıyla zevken (tasavvufî̀ tecrübe ile) yaşanmadan içeriği tam olarak açıklanamayan, "gaflet uykusundan uyanma" diye de ifade edilen özel bir hâldir (el-Herevî, 1988, ss. 11-13; el-Kâşânî, 2004, ss. 596-597, 2005, s. 722).

Şakîk menkıbesinden anlaşılıyor ki yakaza hali, insanın kalbine yüce Allah tarafından bahşedilen ilahi bir ikramdır. Bu hâli yaşatan tesir, yaşanılan olaydaki insanların sözlerinin etkisinden kaynaklanan bir durum değil, etkilenen insanın duygu alemindeki yaşantısında bazı aşamaların vaktinin geldiğini belirten ilahi bir programın parçasıdır. Bu yargıya varılmasını destekleyici nitelikte, sûfînin duygu dünyasında yaşadığı hâllere başka örnekler çoktur. Sufi tezkire ve tabakat eserlerinde, gaflet uykusundan uyanma konulu Şakîk'in menkıbesindeki zecr, intibah, teyakkuz, yakaza ve tövbe duygularının yaşandığına örnek başka menkıbeler de bulunmaktadır. (Ayrıntı için bakılabilir: Attâr, 2012, ss. 96, 113, 126, 155, 156, 172, 210, 253, 364.) ${ }^{1}$ Şakîk-i Belhî’nin Budist rahibin sözünden etkilenmesi menkıbesinde kaderin bu iki kişiyi böyle bir soru ile karşı karşıya getirmesi durumundaki tecelli her iki kulun iradeleri dışında gerçekleşen ilahi mevhibedir. Bu argümanlar işığında tekrar değerlendirildiğinde Şakîk-i Belhî’nin zühd yoluna yönelmesinin Budist rahibin mensubu bulunduğu dinin kültürel baskınlığının İslam dininden daha fazla olduğu ile ilgili bir değerlendirme, tasavvuf biliminde tövbeye ulaşma aşamaları olan "zecr, intibah, teyakkuz, yakaza" kavramlarıyla çeliştiği için isabetli değildir. Şakîk-i Belhî’nin zühd yoluna girmesinin Budist rahibin etkisiyle olduğu veya

\footnotetext{
${ }^{1}$ Okunan bir ayetten etkilenme sonucu gaflet uykusundan uyanmaya örnek; Fudayl b. Iyad, Bâyezîd-i Bistâmî ve Ebu Hafs el-Haddâd. Yine bir başka rivayette Yahudi dinine mensup birisinin sözünden etkilenen Ebu Hafs elHaddâd. Hz. Hızır'ın sözünden etkilenen İbrahim b. Edhem. Bir cariyenin sözünden etkilenen Zünnûn el-Misrî, Abdullah b. Mübarek. Ağıtçı kadının okuduğu beyitten etkilenen Dâvud-1 Tâî. Âşık olduğu bir kadının cevabından etkilenen Utbe b. Gulâm.
} 
Şakîk'in, Hint mistik felsefesinin İslam tasavvufuna girmesinde aracı olduğu şeklindeki bahse konu iddia, sûfîlerin yaşadıkları samimi hâllerin kapsamı dışında kalmaktadır. Şakîk-i Belhî’nin Hindistan'daki bir Budist rahibin sözünden etkilenerek Budizm dinine özgü ögütleri yaşayarak yabanc1 kültürden etkilenme sonucunda yaşam şeklini değiştirip İslam tasavvufunun öngördügü zühd yaşantısını benimsediği, bu tercihinde Hint mistik kültürünün etken olduğu, daha sonra da İslam dininin bir rüknüymüş gibi Hint mistik felsefesini çevresine öğrettiği iması zorlamaya dayalı bir yorumdur. Çünkü bu görüşe temel oluşturduğu varsayılan ilmî veri (menkıbe), yukarıda da açıklandığı üzere tasavvuf bilimi literatüründe yer alan tövbe ile ilişkili "yakaza" teriminin içeriğiyle ve yine Şakîk-i Belhî’nin elimizdeki eserlerde yer alan tarihi şahsiyetiyle örtüşmemektedir. (Şakîk-i Belhî’nin kişiliği konusunda ayrıntı için bakılabilir: Attâr, 2012, ss. 228-235; Attar, 1905, s. 1/196-202; Câmî, 2001, s. 173; el-Yâfiî, 1997, s. 1/341; E. A. b. A. el-Hatîb el-Bağdâdî, 2002, s. 4/90; es-Sülemî, 2003, ss. 61, 66; eş-Şârânî, 1997, s. 1/110; ez-Zehebî, 1985, s. 1/315, 1996, s. 9/313-316; Hücvirî, 2007, s. 323; Isfahânî, 1988, s. 8/37, 53, 58-59, 64, 66, 69, 72-73; İbn Hallîkân, 1978, s. 1/26, 32; 2/475-476; İbn Mulakkîn, 1994, ss. 12, 14, 44; İbnü'l-Cevzî, 1992, s. 4/160; E.-K. Z. A. b H. Kuşeyrî, 1991, s. 124. )

Ayrıca Şakîk-i Belhî’nin ticareti bırakıp da zühd yolunu benimseyen bir derviş olmasına Hindistan seyahatinde karşılaştı̆̆ Budist Türklerin sebep olduğu şeklinde Erol Güngör'ün nakli (Güngör, 1993, s. 230 (Dipnot 3)), Kuşeyrî’nin er-Risâle adlı eserinde geçen menkıbede Hindistan'a vurgu yapılmaması ve Budist rahibin milliyetinin belirtilmemesi gerçeğiyle çelişmektedir. Yine Şakîk'in yaşadığı dönemde Hindistan yolu üzerinde bulunan ve Türklerin ikamet ettiği tarihi Türkistan bölgesinde yaygın olan tapınaklardan birisinde olayın geçme ihtimali de söz konusu olabilir.

\section{5. İbrahim b. Edhem'in Hayat Hikayesini Buda'nın Hayatına Benzetme}

Ebu'l-Ala Afîî (ö. 1966) erken dönem sûfîlerinden Horasan Belhli İbrahim b. Edhem'in hayat hikayesinin Hindistan'da yaşayan Budizm'in kurucusu Gotama Buda'nın (m.ö. 563-483) kıssasına benzediği iddiasından (Chand, 1936, s. 67) hareketle Budizm'in İslam tasavvufunu etkilemiş olabileceği ile ilgili Goldziher'in (ö. 1921) (Ayrıntı için bakılabilir: Hatiboğlu, 1996, s. 14/102-105.) Vorlesungen über den Islam adlı kitabının "Asketismus und Sufismus" başlıklı dördüncü bölümünde yer alan görüşünün doğru olabileceğini belirtir. (Afîfî, 1996, s. 94, t.y., s. 58) Goldziher bu iddiay1 savunurken dayanak olarak aldığı görüşlerinden birisi şudur: "İslâmiyet Mekke'nin Yahudileştirilmiş dini âdetleridir, ancak Yahudiliğin kendisi değildir.” (Görgün, 1996, s. 14/105-111) Bu ifadede Yahudi kültürünün Hristiyanlık ve İslam dininden önce var olması nedeniyle tüm dünya kültürlerini etkileyen egemen dini güç olduğu anlayışı var gibi gözüküyor. Bu anlayışa benzer bir şekilde sonradan ortaya çıkan bir inançta aynı coğrafyada İslam öncesinde hâkim olan inancın etkisinin İslam üzerinde olabileceği varsayımıyla Belh ve civarında bulunan büyük tapınaklar aracılığıyla Budizm'in sonrasına baskın inanç olduğunu savunan Afîfî, İbrahim b. Edhem'in yaşadığı Belh kentinin İslam'ın fethinden asırlarca yıl önce Buda mistisizminin en önemli merkezlerinden birisi olması ve bir çok eski Budizm manastırına Belh ve civarının merkezlik etmesini delil göstererek Horasan meşâyihinden Şakîk-i Belhî’nin yanı sıra Ebu Hamid b. Hadraveyhî, Bâyezîd-i Bistâmî gibi o bölgede yaşamış olan mutasavvıfların çoğunun Hint kültüründen etkilenip İslam tasavvuf anlayışlarını yabancı bir kültür üzerine inşa ettiklerini savunmuştur. (Afîfî, t.y., s. 78)

Goldziher'in görüşlerinin bir kısmına katılan Hindistanlı Tara Chand'a (ö. 1973) göre, Kelile ve Dimne (Panchatantra), Kitab-ı Sindbad gibi hikâye kitaplarının yanı sıra astronomi, tıp vb. alanlarda

\footnotetext{
${ }^{2}$ Ignaz Goldziher Macar asıllı Musevî bir müsteşriktir. Alman Theodore Nöldeke ve Hollandalı Christian Snouck Hurgronje'yle beraber Avrupa'da İslâmî incelemelerin kurucusu olmuş ve Batı İslâmoloji çevrelerinde yeni İslamiyatçıların mânevî babası sayılmıştır. Kahire'de Ezher hocalarının derslerini takip etmiş ve Ezher talebesi cübbesini giyen ilk gayrimüslim Avrupalı olmuştur.
} 
Müslüman Arapların, Hint edebiyatı ve bilimleri ile erken dönemlerde tanışmışlardır. Ona göre tasavvuf tarihinde iki dönem ayırt edilebilir: Birincisi İslam'ın ilk dönemlerinden miladi dokuzuncu yüzyılın başına kadar olan dönemdir. İkincisi ise miladi dokuzuncu yüzyıldan itibaren olan dönemdir. İlk dönemde tasavvuf sadece amacı olan ve zühd olarak yaşanan, ancak hiçbir sistemi olmayan bir ilimdi. İkinci dönemde ise, metafizik sistemlerin ve manastır düzenlerinin organizasyonuna benzer olarak entelektüel şekilde sistemleşip kurumsallaşmış ve kendisini geliştirmiştir (Chand, 1936, s. 67).

Annemarie Schimmel de (ö. 2003) "Tasavvufun Kaynăg 1 ve İlk Dönemi” (The Origin and Early Development of Sufism) adlı makalesinde bu konuyu şöyle değerlendirir: "Hitopadeśa ve Panchatantra gibi Hint kaynaklı halk hikâye ve masalları, İslam'ın doğuşundan çok önceleri pek çok Yakın Doğu diline çevrilmiş ve artık o kültürlerin bir parçası olmuştu. Din ve ahlak konulu masal ve hikayelerde anlatılan olağanüstü insan tipleme ve nitelikleri (Buda'nın hayat hikayesi) ile bazı İslam tasavvuf kitaplarında zikri geçen evliyaya (İbrahim b. Edhem'e) atfedilen kerametler arasında yüzeysel paralellikler kurmak çok kolay bir iştir. Dolayısıyla da bu tür yüzeysel benzerlikler üzerinden hareketle iki literatür arasında direk bir illiyet bağı kurmak ve İslam tasavvufunun Hint menşeli olduğunu ispata koyulmak ilmî açıdan bir değer ifade etmez" (Yaman, 2016, s. 22).

\section{Bâyezîd-i Bistâmî’ye Ait Zikri, Yoga Nefes Kontrolüne Benzetme}

Murâkabe-i enfâs denilen nefes kontrolü metodunu Ebu Ali Sindî’den aldığı iddia edilen Bâyezîd-i Bistâmî'nin ve Horasan mutasavvıflarının Hint kültüründen etkilenip İslam tasavvuf anlayışlarını yabancı bir kültür üzerine inşa ettikleri savunulmuştur (Afîfî, t.y., s. 78). Ebu Ali Sindî ile ilgili tartışma Oxford Üniversitesi'nde Dinler Tarihi hocası olan İsviçre kökenli İngiliz Robert Charles Zaehner'in (Carlo, t.y.) Hindu And Muslim Mysticism (Hinduizm Dini ve İslam Tasavvufu) adlı kitabının 1960 yılında yayınlanmasıyla tekrar gündeme gelmiştir (Zaehner, 1969). "Zikr-i habs-i nefes" veya "murâkabe-i enfâs" denilen "nefes kontrolü metodu"nun Hindu dinine mensup olan Ebu Ali Sindî'den alındığı iddia edilen görüşe dayanak olarak gösterilen ve Bâyezîd-i Bistâmî'den nakledilen sözün alıntı yapıldığı kaynak olarak (Böwering, 1989, s. 4/183-186) Afîfî, eserinin dipnotunda sayfa belirtmeden Attâr'ın Tezkiretü'l-Evliya'sını vermektedir (Afîfî, t.y., s. 78). Ancak Attâr'ın Tezkire'sinde böyle bir nakil yoktur. Bu durum, Tezkiretü'l-Evliya'nın çeşitli nüshalarındaki metin noksanlıkları veya hataları ile ilgili olabilir (Attâr, 2012, ss. 27-28). Tespit edebildiğimiz kadarıyla Afîfi’’nin bahsettiği alıntının bulunduğu kaynak Abdülhay el-Hasenî’nin de alıntı yaptığı Ebu Nasr Abdullah Serrâc'ın (ö. 378/988) el-Lum 'a 'sıdır. Orada geçen metin şöyledir: (بال أبو يزيد البسطامي Bâyezîd-i Bistâmî, "Ebu Ali Sindî ile sohbet arkadaşı oldum, ben ona farzları yerine getireceği bilgileri öğrettim. O da bana tevhidi ve hakikatler ilmini öğretti" dedi. Aynı metni Şehabeddin Ömer es-Sühreverdî de nakletmektedir (et-Tûsî, 1380, s. 235; Hasenî, 1962, s. 1/53; Sühreverdî, 1990, s. 515).

$\mathrm{Bu}$ anlatılanlardan ilmî bir bakış açısıyla çıkarılabilecek muhtemel sonuçlardan bazıları şunlar olabilir: "Bâyezîd-i Bistâmî, Ebu Ali Sindî isminde bir şahısla sohbet edip konuştu. Bâyezîd-i Bistâmî, Ebu Ali Sindî’ye farzları ikame edeceği bilgiler sunuyordu. Ebu Ali Sindî ise, Bâyezîd-i Bistâmî'ye İslam dininin tevhit ilmini ve hakikatler ilmini öğretiyordu." Metinde "Ebu Ali Sindî, Bistâmî’ye murâkabe-i enfâsı öğretti” ifadesi veya bunu çağrıştırabilecek bir anlatım geçmemektedir. Söz konusu metinde sadece genel olarak İslam dinindeki tevhid ilmi ve hakikatler ilminden bahsedilmektedir. Tasavvuf ilminde tevhid ilmiyle kastedilen fenâ ve bekâ mertebeleridir. Tecellileri müşahede sonucu edinilen marifet ve hakikatlerin mahiyeti ise, tasavvuf alanında uzman olanlarca malumdur. Hakikat, kulun çaba ve çalışması sonucu değil, sadece ilahi mevhibe ile edinilirken yoga nefes kontrolü, aklın ürünüdür. Yine İslam tasavvufundaki hakikat anlayışı ile varılmak istenen hedef, yoga uygulaması sonucu varılması düşünülen hedeften amaç birlikteliğinin olmaması yönünden taban tabana zit olacak şekilde farklıdır. Birbiriyle hiç örtüşmeyen teknik ayrıntılarda da açıkça görülüyor ki bahse konu 
iddiada bir niyet okuma ve istismar söz konusudur. Hint kültüründe yoga eğitimindeki nefes kontrolü ve İslam dininde zikir ibadetini ifa ederken yapılan nefes alıp verme arasındaki içerik ve şekil yönünden benzerlik konusuyla, metnin orijinali arasında doğrudan bir bağlant1, hatta bir emare veya maddi bir karine (ipucu) bulunmamaktadır. Bu iddiadan yaklaşık yedi yüz elli yıl önce yazılmış bir eserde geçen Bâyezîd-i Bistâmî’nin şu sözü onun karakterini ve bu konuya bakış açısını yansıttı̆̆ı gibi hakkındaki olumsuz iddialara cevap gibidir: "Eğer birisinin havada bağdaş kurup oturacak kadar olağanüstü olaylara sahip olduğunu gözlerinizle görseniz, ona aldanmayınız. Zira o adamın Allah'ın emirlerini, yasaklarını ve Allah'ın çizmiş olduğu sınırları nasıl koruduğunu ve dini kurallara bağlılık anlamında şeriatı nasıl uyguladığını görene kadar dikkatli olunuz"”3 (E.-K. Z. A. b. H. el-Kuşeyrî, 1991, ss. 13, 127). Bazı oryantalistlerce sürdürülen bahse konu iddiada aslından uzaklaştırılan hakikat kavramının içi boşaltılmaktadır. Üstelik bu iddiada yoga ve riyazet ile edinilen olağanüstü hâller gösterme (istidrac) konusunun bir sonraki aşamasında, zikir ile ulaşılan keramet gösterme motifiyle bağlantılı olan tasavvuf ilminin hakikat kavramını birleştirme eğilimi gözlemlenmektedir. Anlaşılan o ki bu konuya genel yaklaşımını belirten Bâyezid-i Bistâmî’nin yaşadığı yıllardaki yukarıda nakledilen görüşü, kendisinden yüz yıllar sonraki varsayıma dayalı bir iddiadan daha fazlasını ifade etmektedir.

Bâyezîd-i Bistâmî'nin yaşadığı yıllardan sonraki tarikatlar döneminde nefesi tutma kontrolüyle zikir konusunda mutasavvıflarca genel kabul gören bir rivayet bulunmaktadır. İslam tasavvuf kaynaklarına göre nefes kontrolüne dayalı zikr-i habs-i nefes (nefesi tutarak yapılan zikir) Hızır (a.s.)'in Nakşbendiyye tarikatı piri Abdülhâlık Gucdüvânî’ye (ö. 575/1179, 617/1220) (Algar, 1996, s. 169) havuzda suya dalış yaptırarak kelime-i tevhidi zikretmeyi öğretmesiyle başladığı nakledilir. Habs-i nefes zikri konusundaki rivayet şöyledir: Yetişme çağında tahsil için Buhara'ya giden Abdülhâlık Gucdüvânî, şehrin önde gelen âlimlerinden İmam Sadreddin'in yanında tefsir dersi okurken "Rabbinize yalvara yakara ve gizlice dua edin" (el-A`râf 7/55) ayetinin yorumuna sira geldiğinde bu ayette geçen "gizli duanın" ne anlama geldiğini hocasına sorar. Hocası, ilm-i ledünne ait olan bu meseleyi nasibi varsa ileride öğrenebileceğini söyler. Rivayete göre bir müddet sonra Gucdüvânî bağda otururken Hızır (a.s.) onun yanına gelir ve oradaki havuza dalmasını, suyun altındayken kelimei tevhidi zikretmesini Gucdüvânî’den ister. Böylece Gucdüvânî ayette geçen gizli dua veya gizli zikir sorusunun cevabını bulur. Bu nedenle Hızır (a.s.) Gucdüvânî’nin pir-i sebâkı yani habs-i nefes zikrini telkin eden piri olarak kabul edilir (Tosun, 2015, ss. 51, 52). Nakşibendi kaynaklarında da nefes tutularak yapılan gizli zikrin, Hz. Hızır'ın talimiyle suda kelime-i tevhid zikri ile başladığı rivayeti esas alınır (Tosun, 2015, s. 360 (Dipnot 31). Yani bu tür zikir, yogada olduğu gibi aklın ürünü değildir, kulun çalışarak üretmediği ilahi bir ikramla bahşedilmiştir.

Nefesi tutarak yapılan zikir uygulamasının (habs-i nefes) Hindistan'a ilk gelen Çiştiyye tarikatı aracılığıyla oradaki yogilerden İslam tasavvuf uygulamalarına alındığı görüşü ise kabul görmez. Çünkü Siczli (Sistanl1) olup Mu’izzeddin b. Sam (ö. 589/1193) devrinde göç eden ve Hindistan Ecmîr/Acmer'de yerleşen Muînüddin el-Çiştî (ö. 633/1236) tarafından bu tarikatın Hindistan'a getirildiği söylenmektedir (Margoliouth, 1987, s. 3/435-436). Ancak Çiştiyye tarikat1, Muînüddin elÇiştî Hindistan'a gelip yeni yayılma imkânı aradığı zamanda zor bir dönem yaşamıştı. Hindistan'da Çiştiyye tarikatının temellerini atan ve tarikatı Şah Cihan'ın iktidar merkezi olan Ecmîr'de yaymaya çalışan Muînüddin Hasan el-Çiştî’nin, yabancılara kuşku ile bakan yerel halkın gözetimi altında nasıl bir yöntemle çalıştığını ayrıntıları ile veren sıhhatli bilgiler mevcut değildir. Çok sayıda insanın onun dergâhına koştuğu, Ecmîr'deki ikametinin kast mensubu Hindularca hiç de hoş karşılanmadığı bilinmektedir. Muînüddin el-Çiştî, İltutmış'ın hükümdarlığı döneminde (1210-1235) Delhi’yi iki defa ziyaret etmiş, ancak siyasî güç merkezinden kendisini uzak tutarak kır kesiminde faaliyet göstermeyi

\footnotetext{
${ }^{3}$ Kuşeyrî er-Risâle'sini 437/1045 yılında yazmıştır. H. Z. Ülken'e göre İslam tasavvufundaki Hint tesirini tarihte ilk defa İngiliz oryantalist Sir William Jones (ö. 1794) ileri sürmüştür. 1794-1045=749. Kuşeyrî’nin eseri ise bu iddialardan yaklaşık 750 yıl önce yazılmıştır.
} 
tercih etmiştir. Bu tutumu bile onun nasıl zor dönemlerden geçtiğinin bir göstergesidir (Nizami, 1993, s. 343). Yani Çiştî’nin Müslüman devlet idaresinden İslam kaynaklı olmayan uygulamalar nedeniyle tepki alabileceği bir gerçektir. Yabancı kaynaklı olduğu iddia edilen habs-i nefes yöntemini Şeyh Çiştî‘nin oradaki yogilerden almasının, Çiştiyye şeyhleri-Hint yogileri mücadelesini yansıtan Osmanzâde Hüseyin Vassaf' in "Hindistan'da gayet meşhur bir hikâye" şeklinde naklettiği olay gibi tarihi gerçeklerle de örtüşmemektedir. Bu bağlamda Muhammed Tuğluk'un saltanatı döneminde (725752/1325-1351) Hint mistikleri olan ve Hint fakirleri diye de adlandırılan yogilerin ve saduların İslam tasavvufundan nasıl etkilendiklerine dair Osmanzâde'nin dikkat çektiği olay, Hint mistisizminin İslam tasavvufunu etkilemesinin aksine İslam'ın Hint mistisizmini etkileyecek kudrete sahip olduğunu göstermektedir. Bahse konu olay devlet erkanının ve büyük halk kitlesinin önünde gerçekleşmiştir. Yogi ve sadulardan oluşan bir grup, Muhammed Tuğluk'un huzuruna çıkıp Hindistan'daki Müslümanların kendi inançlarını ve yaşam şekillerini benimsemeleri için bir gösteri düzenlemek istediklerini Sultana arz ederler. Bu konuda İslam âlimlerinin kendileriyle yarışamayacaklarını söyleyerek meydan okurlar. Bir yogi yere bağdaş kurup bedenini havaya kaldırır, uzun süre havada sabit şekilde durur. Çiştiyye tarikatını Hindistan'da yayan Şeyh Muînüddin el-Çiştî de yere bağdaş kurup ayakkabılarını önüne koyar. Bir süre sonra onun ayakkabıları havada duran yoginin kafasının üstüne çıkar. Boşlukta duran ayakkabılar kendi kendilerine yoginin başına vurarak onun yere inmesini sağlar. Cansız nesneleri Allah'ın izniyle bir amaç için hareket ettirme keramet motifini gören yogilerin ve saduların çoğu Müslüman olur (Hüseyin Vassaf, 2011, s. 2/424-425).

Bu olayda da görüldüğü üzere taraflar arasında bir çekişme söz konusudur. Böyle bir ortamda habs-i nefes uygulamasının Çiştiyye tarikatı aracılığıyla Hint yogilerinden alınmış olma ihtimali, Hindistan'a ilk gelen tarikatın yeni yayılma sürecinde hasımları tarafindan aleyhine kullanılabilecek önemli bir veri olurdu. Bu durum Bâyezîd-i Bistâmî’nin haksız yere Hint kültürüyle ilişkilendirilmesi ile sınırlı kalmazdı. Yine Gucdüvânî’nin söz konusu rivayete göre tarihi süreç olarak Muînüddin el-Çiştî’den daha erken bir dönem olan tahsil çağı sürecindeyken habs-i nefes zikrini Hızır (a.s.)'dan öğrendiği yukarıda değinildiği üzere İslamî kaynaklarda geçmektedir. Ayrıca Hindistanlı âlim Şah Veliyyullah Dehlevî (ö. 1176/1762) Hint yogilerinin habs-i nefesi dünyevi maksatlarla yaptıklarını, oysa sûfîlerin ahiret merkezli bir anlayışla nefsi tezkiye etmek için bu usulü kullandıklarını söyleyerek benzerliğin söz konusu olmadığı gibi amaçtaki ve niyetteki büyük farklılıklara da dikkat çekmektedir (Tosun, 2015, s. 303).

Goldziher tarafından devam ettirilen İslam tasavvufunun Hint kültüründen beslendiği varsayımı ile Zaehner'in gündeme getirip Afîfî'nin de katkıda bulunduğu Bâyezîd-i Bistâmî'ye bazı tasavvufî incelikleri öğreten Ebu Ali Sindî’nin aslında Bistâmî’ye Hint kültürünü öğreten Hintli birisi olduğu varsayımını, ilmî gerçeklere uymadığı için tutarsız bulan Annemarie Schimmel, Bâyezîd-i Bistâmî ile arkadaşlı̆̆ından söz edilen Ebu Ali Sindî’nin doğum ve ikamet yerinin şüpheli olduğunu, Bâyezid'in vefat y1l 234/848 veya 261/875 olduğundan hareketle o dönemde Hindistan'1n Sind bölgesinde tasavvufî bir yaşantının derinliğinin ölçütünün tam olarak bilinemediğini, orada yaşayan Ebu Ali Sindî diye birisinin de tespit edilemediğini, Ebu Ali’nin günümüz coğrafyasında kuzeydoğu Afganistan'dan Pakistan'a ve Hindistan'ın kuzeybatısına kadar uzanan İndus vadisinde çok geniş bir coğrafyada bulunan Sind bölgesine mensubiyetinden ziyade Bistâm'a yakın bir köy olan Sind halkından birisi olabileceğini belirtir (Schimmel, 1980, s. 6).

Bâyezid'in menkıbesinden hareketle Hindistanlı olduğu var sayılıp iddia edilen Ebu Ali'nin, murâkabe-i enfâsı Bâyezîd-i Bistâmî’ye öğretmesiyle Müslümanların Hint kültüründen etkilendiği görüşünün dayandığı deliller yukarıda da belirtildiği gibi genelde tutarsız bulunmaktadır. Burada şunu belirtmekte fayda var: İnsanlığın ortak kültüründeki zenginliklerin, bir kültürün özünde zaten var olan bir anlayışa olumlu anlamda katkı sağlaması, insanlık tarihi boyunca olagelmiş kaçınılmaz bir olgudur. 
Ancak bu durum manevi desteği bulunan vahye dayalı din anlayışı için gerekli değildir. "Allah'1 zikretmek elbette ibadetlerin en büyügüüür" (Ankebût 29/45) ve "Siz beni zikrediniz ben de (size vereceğim ilahi yardımlarımla) sizi zikredeyim" (Bakara 2/152) ayetleri gibi diğer ayetlerde de belirtilen ve Kur'an kaynaklı İslam tasavvufunun özünde zaten var olan "zikir" anlayışının bir başka kültürün nefes kontrol yöntemlerinden birisinin farklı bir ülkede bulunan ve Peygamberimizin damadı Hz. Ali'nin adını çocuğuna vermesinden (Ebu Ali=Ali'nin babası) İslami değerlere önem verdiği düşünülen bir kişinin geliştirdiği iddia edilen zikrin yoga nefes kontrolüne benzetilmesi, dinin özünde hiç olmayan bir şeyi başka bir dinden alarak senkritik yeni bir tasavvufî din anlayışı oluşturmaya örnek teşkil etmez. Ancak İslam tasavvufu, Hint mistik felsefesinden etkilendiyse, bu etkilenmede yukarıda sözü edilen Horasan meşâyihinin ve özellikle Bâyezîd-i Bistâmî ve Şakîk-i Belhî’nin yabanc1 kaynaklı olduğu iddia edilen görüşlerinin İslam tasavvuf anlayışını köklü bir değişime dönüştürecek etkilerinin bulunduğu konusunda, sözü edilen varsayımların dışında herhangi bir ilmî veri mevcut değildir.

Bazı tasavvufî uygulamalar ile yoga ve meditasyon uygulamaları arasındaki benzerlikler de kimi araştırmacılar tarafindan istismar edilmektedir. Örneğin İslam tasavvufunda bulunan latâif-i hamse, zikr-i erre, nefsin yedi mertebeleri gibi bazı tasavvufî uygulamaların, Hint mistisizmindeki bazı kavramlarla benzerlik gösterdiği belirtilmektedir. Carl Ernst'in yoga ile tasavvufî ibadetlerin benzerliğinin olup olmadığ 1 konusundaki incelemesi ve yorumu konumuzla ilişkili olduğu için değinmekte yarar var. Sufiler tarafindan geleneksel tasavvufî meditasyon (seyr ü sülûk ve riyazet) sürecinde dikkate alınan manevi latâif (kalp, ruh, sır, hafi, ahfa latîfeleri) (Küçük, 2012, s. 52; Özköse, 2013, ss. 22-24) olgusunun ve Allah'ın doksan dokuz isminden müteșekkil zikir formüllerinin ve zikirde nefes kontrolü (zikr-i erre vb.), yogadaki çakra fizyolojisi ve mantraların kuvvet boyutlarını ihtiva eden yoga öğretilerine benzetilse de her sistemin içerisindeki kendine özgülük göz ardı edilmemelidir. C. Ernst yoga uygulamalarını belgeleyen ve ayrıca yogayı resimlerle tanıtan son temel Farsça kaynakların, Müslüman yazarlar tarafından değil de Türk-Moğol kökenli Bâbür devletinin son idaresi bünyesinde çalıştıktan sonra yeni kurulan İngiliz müstemleke idaresinde çalışmaya devam eden Hindu kökenli kâtiplere (münşîlere) İngilizler tarafından yazdırıldığına dikkat çeker. O yüzden Farsça olup da müellifi belirsiz, İslami olduğu iddia edilen ancak Müslüman olmayan Hindu dinine mensup bu âlimlerin siyasi amaçla yazdığı, Anglo-Fars (İngiliz yönetimi kontrolü ve yönlendirmesiyle yazılan Farsça eserler) diye nitelendirilen telif ve derleme eserlere Ernst, temkinli yaklaşmak gerektiğini belirtir $^{4}$ (W. Ernst, 2003, ss. 199-226, 2014, ss. 117-128). Özellikle İngilizlerin Hindistan'a egemen olması sonrasında Hinduizm'in etkisiyle İslam'a sokulmaya çalışılan bid'at ve hurafelere karşı duyulan entelektüel tepki, Şah Veliyyullah Dehlevî’nin öncüsü olduğu hareket ve önderliğini Seyyid Ahmed Barelvî'nin yaptı̆̆ Mücâhidûn Hareketi, İngiliz Sömürgesi ve Sihlere karşı cihat başlatmıştır. Günümüz Hindistan ve Pakistan'ındaki yaygın olan İslam düşüncesi, İslam mezheplerine sentetik ve ihtiyatlı yaklaşımın izlerini taşımaktadır (Ahmed, 2001, ss. 536-541).

Hindistan ve civarında yogilerden ve sadulardan ziyade İslam mutasavviflarının saygınlığının daha etkin olduğuna dair örneklerden birisi de Kâzerûniyye tarikatının kurucusu, Ebu İshak İbrahim elKâzerûnî'nin (ö. 426/1033) İran'da yaşamasına rağmen Hind ve Çin halkının ona çok saygı duydukları, deniz aşırı seyahat edenlerin onu mutlaka ziyaret ederek duasının bereketiyle denizlerdeki

\footnotetext{
${ }^{4}$ Yoga konusuna ayrılmış ilk temel Farsça kaynak, on dördüncü yüzyılda, bilinmeyen (anonim) bir yazar tarafından, "Kamarupa Çekirdeği Heceleri”" başlığıyla derlenmiştir. Bu başlık, geleneksel olarak tılsım ve olağanüstü olayların kaynağı olarak Hindistan’ın kuzey doğusundaki Kamarupa'ya (Assam bölgesine) göndermede bulunmaktadır. Bu konudaki diğer eser, tarihi karmaşık olan "Hayat Suyu Havuzu”dur. Ernst'e göre nüshalardan birisinde sahte İslam görünümü, diğerinde Hint özelliği ağır gelen yapay görünüm belli olmaktadır. On dokuzuncu yüzyılın sonlarına doğru Arapça metin, iki defa Osmanlı Türkçesine tercüme edilmiş ve İstanbul'daki Mevlevi tarikatı mensuplarınca önemsenmiştir. Günümüzde bahse konu eserin İbnü'l-Arabi'ye yanlışlıkla atfedilen bir eser olduğundan da bahsedilmektedir.
} 
afetlerden kurtuldukları bilgisiyle bağlantılı olduğu görülen ve Hodgson'un (ö. 1968) eserinde 12581503 yılları arasında İslam'ın Hindistan ve civarında yayılışını değerlendirdiği görüşlerinin önemli olduğu düşünülmektedir. Hodgson, özellikle Doğu'da İslam'ın yayılışının Hint kültüründeki etkisinin Avrupa kültüründeki etkisinden daha kesin bir şekilde belirleyici olduğu, Sanskrit medeniyetinde sadece büyük ölçüde İslamileşmiş kuzey Hindistan'daki eski merkezler değil, güney Hindistan'da da İslam egemenliğinin etkin olduğu görüşüne yer vermektedir. Bunun sebebi olarak uluslararas1 İslamileşmiş kurumların siyasi ve sosyal esnekliği, İslamileşmiş kültürün temellerinin yeni mühtedilere nisbî ulaşabilirliği kadar önemli olmasının yanı sıra dini davette görev alan tasavvufî akımları temsil eden sûfî hankâhlarında mürit adayı olan kişide iç zenginliğinin daha önemli tutulması sayesinde entelektüel ve duygusal ikna metoduyla bireysel kazanımdan hareketle toplumsal kazanıma doğru özelden genele, tikelden tümele bir yöntem izlenmesinin sağladığı başarıya dikkat çekmektedir. İslam medeniyeti ve kültürünün Hint medeniyetinden etkilenmediğine, tam tersine İslam kültürünün tüm çağlarda Hint kültürünü etkileyecek kadar kuvvetli olmasına da vurgu yapmaktadır (Hodgson, 1974, s. 2/532, 535, 536). Hodgson'un bu tarafsiz yorumu önem arz etmektedir.

\section{Tasavvufi Tecrübeyle Edinilen Fenâ Hâlini Nirvana'ya Benzetme}

Nirvana, Buda'nın kurtuluş öğretisidir. Nirvana'ya ulaşabilmek ancak Buda'nın sekiz dilimli yolu ile mümkündür. Ahlak, meditasyon ve hikmet şeklindeki üç ana maddenin sonradan geliştirilmiş şekli olan sekiz dilimli yol şunlardır: Doğru söz, doğru davranış, doğru geçim, doğru muhakeme, doğru murakabe, doğru anlayış, doğru düşünce, doğru niyet. Nirvana her türlü duygudan, istek ve tutkudan kurtulma hâlini, içgüdülerin yönlendirmesinin sonunu ve benliğin tamamen ortadan kalkmasını belirten, rahatlatıcı iç dinginliğe ulaştıran aydınlanmış en yüksek ruh halidir (Tümer, 1992).

Robert Charles Zaehner Hindu And Muslim Mysticism adlı kitabında Reynold Nicholson'a (ö. 1945) ait The Mystics of Islam'ı referans vererek Bâyezîd-i Bistâmî'nin İslam tasavvufundaki manevi hâllerden olan fenâ öğretisini yukarıda da bahsi geçtiği üzere Ebu Ali Sindî isimli Hint mistiğinden aldığını iddia etmiştir. Halbuki Ebu Ali’nin doğup büyüdüğü yer olan Sind'in, Hindistan beldesi olmayıp Horasan'da bir köy olduğunu Arthur John Arberry (ö. 1969), Yâkût el-Hamevî'nin (ö. 626/1229) eserine dayandirarak nakletmektedir (Nicholson, 1914, s. 17; Zaehner, 1969, s. 93). Zaehner'in alıntı yaptığı aynı eserde Arberry'nin on üçüncü yüz yıl İslamî kaynaklı bir eserden yaptığı alıntının önemsenmemesi oldukça düşündürücü bir konudur.

İslam'a Hint tesirinin diğer konusu olarak İslam tasavvufundaki manevi hâllerden olan "fenâ" anlayışının, Hint dinlerinden Budizm'de öne çıkan nirvana inancının bir çeşidi olabileceğini ileri sürenlerin görüşlerini (Chand, 1936, ss. 67, 69, 79) Ebu'l-Ala Afîfî reddeder. Ona göre fenâ kavramının olumsuz (selbi) karakteri olmakla birlikte, olumlu (icabi) karakteri de bulunan ve tabii yapısı itibarı ile kötümser felsefenin hiçbir rolü bulunmayan bir kavram olmasına karşın nirvana tamamen olumsuz bir yapı arz eder ve genel kötümserlik ekolünün bir dalıdır. Bütün bunlara rağmen Afîfî, Hint dinlerinin değil de Hint mistisizminin dini ritüellerinden, riyazet egzersizlerinden ve nefis ile mücahede yöntemlerinden sûfîlerin etkilendiğini düşünmektedir (Afîfî, t.y., ss. 58, 77).

Kur'ân-1 Kerîm'de fenâ-bekâ terimlerinin her ikisinin beraber kullanılan türevleri geçmektedir.

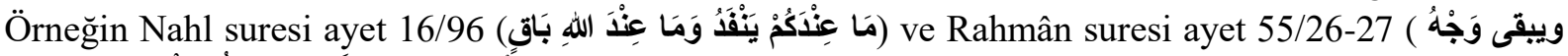

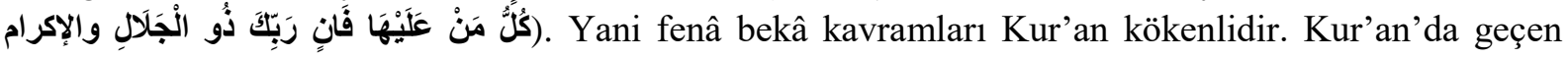
ayetteki manaya, sûfîlerce farklı anlam verilmemektedir ve bu çizgide tefsirin önü açıktır. Kur'an'da, kula ait olan maddi ve manevi özelliklerin gelip geçici, Allah'ın katına kulun gönderdiklerinin ise sonsuzluk kazandığı vurgulanmaktadır. Bu ayetlerden hareketle İslam'in kutsal kitabı, Hint mistisizmindeki nirvanaya ulaşma öğretisinden alıntı yapmaktadır şeklinde bir yoruma ulaşılamaz. Benzer evrensel doğrular, her sistemin kendi içerisindeki değerlendirmelerle ilişkilendirilerek yorumlanmalıdır. Ayetlerde maddenin el değiştirerek gelip geçici olduğuna, 
maneviyatın ise bireyler için sonsuz yaşamla bağlantısına dikkat çekilmektedir. Sûfîler de fenâ-bekâ yorumlarıyla dünyaya özgü varlıklarından fânî, Allah ile bâkî olma şeklinde ahiret merkezli bir yaşam tarzı anlayışı belirlemektedirler. Bu bağlamda İslam tasavvuf tarihinde Ebu Said el-Harrâz ile aynı dönemde yaşayan Muzaffer b. Ahmed b. Hamdân'ın (Câmî, 2001, ss. 454-455), fenâ-bekâ konusunda yüksek ifade ve güzel beyan tarzına sahip olduğu belirtilir (Hücvirî, 2010, s. 231). Kapsayıcı anlamda sınıflandırarak fenâ-bekâ üzerine ilk konuşan, Bağdat ekolünden Cüneyd-i Bağdâdî’dir (ö. 297/909) (Cüneyd-i Bağdâdî'de fenânın mertebeleri için bk. Ateş, t.y., ss. 153-154). Ona göre fenâ ve bekâ Allah'ın seni sende öldürmesi, kendisinde diriltmesidir (Sunar, 1966, s. 95). Yani benliğin maddi yönünün geçici olduğu, manevi alemde olanın sonsuzluğu değerlendirilmektedir. Cüneyd-i Bağdâdî'nin risalelerinden birisi “Kitâbü'l-Fenâ"dır (Ateş, t.y., s. 229). Cüneyd ile aynı dönemde yaşayan ve onunla görüş alışverişinde bulunan Ebü'l-Mugîs el-Hüseyin b. Mansûr el-Beydâvî elHallâc (ö. 309/922), fenâ ve bekâ öğretisi üzerine "İlmü'l-fenâ ve'l-bekâ" adlı müstakil bir kitap yazmıştır (İbnü’n-Nedîm, 2009, ss. 1-2/678). Fenâ ve bekâ kavramları konusunda "kulun ubudiyeti (yani kulluğuyla ilgili sıfat ve fiilleri nefsine nisbet etmeyi) görmekten fânî olması, ulûhiyetin tecellilerini müşahede ile bâki olmasıdır" (Hücvirî, 2010, s. 308) şeklindeki ifadesi kabul gören Ebu Said el-Harrâz da (ö. 277/890) Cüneyd ve Hallâc ile yakın dönemde yaşayan diğer bir sûfîdir. Fenâ ve bekâ kavramlarına yeni bir bakış açısı kazandıran, bu hâliyle fenâ ve bekâdan söz eden sûfînin Ebû Saîd el-Harrâz (ö. 277/890?) olduğu belirtilmektedir (Câmî, 2001, s. 202; Hücvirî, 2010, s. 309 (14. dipnot); Öngören, 2012, s. 166).

\section{Kalenderî Dervişleri Budist Rahiplere Benzetme Örneği}

Hem içinde yaşadıkları kurulu toplumsal düzenin inanç ve geleneklerini hem diğer dünyevî değerleri önemsemeyen, bunu kılık kıyafet, tutum ve davranışlarıyla gündelik hayatlarına da yansıtan sûfîlere kalender, bunların oluşturduğu tasavvufî topluluğa da genel olarak Kalenderiyye veya Kalenderîlik adı verilmektedir. Melâmetîlik ile Kalenderîlik arasında yakın bir ilişki bulunmaktadır. Kalenderîlik, Cevlekıyye tarikatı kurucusu Cemâleddîn-i Sâvî'den (ö. 630/1233) önce ve sonra olmak üzere iki dönemde incelenir (Yazıcı, 1993). Kalenderî dervişlerin İslam toplumunda geniş ölçüde Hint mistisizminden ve mistik çevrelerinden etkilenerek ortaya çıktığ 1 , buna İslam topraklarında dolaşan Budist ve Maniheist rahiplerin varlığının kaynaklık ettiği, İgnaz Goldziher tarafından Le Dogme et la Loi de l'Íslam adlı eserinde Câhız'ın (ö. 255/869) kitabı referans verilerek delil gösterilmektedir (Ocak, 1999, s. 7). Câhız'ın eserinde geçen metinde "zındıklardan iki rahip kıssası"nı anlatan Ebû Şuayb el-Kallâl'ın Sufriyyûn'dan birisi olduğu geçmektedir. "Sufrî" (صفري) kelimesinin ise "sarı" renkten (İbn Manzûr, 1300, s. 4/460) çağrışım yapılarak Budist rahiplerin giysilerine benzetilmesi doğru bir yorum olmayabilir. Çünkü bahse konu kaynaktaki orijinal metinde geçen "sufrî" kelimesi rahipler için değil, kıssayı anlatan râvî için kullanılmakla beraber dipnotta da açıklandığı üzere "Sufrî", hariciler mezhebinin bir kolu olan Sufriyye fırkasından Ziyâd b. el-Asfar'a veya din dışı yaşantıyı benimseyen (ibâhî) olmalarına işarettir deniliyor. Bu rahiplerin Budizm veya Maniheizm dinine mensup oldukları konusuna eserde açıkça değinilmemektedir. Örneğin Müslüman birisinin Brahmanlara ilgi duyması konusunda Bağdâdî, Esvâriyye'nin görüşlerini anlatırken Nazzâm'dan etkilendiklerini, Nazzâm'ın ise gençliğinde düalist Seneviyyecilerle ve sofist Semeniyyecilerle arkadaş olduğunu, ayrıca onun ibâhîlerden olduğunu, Brahmanların görüşlerine hayranlık duyduğunu açık bir şekilde yazmaktadır (A. el-Bağdâdî, 1991, ss. 65-66, 96, 110). Ancak Câhız'ın hocası İbrâhîm enNazzâm (ö. 231/845), tasavvufî yönü olmayan Mutezile kelamcısı olması nedeniyle İslam tasavvufuna Hint etkisi konusunun dışında yer almaktadır. Üstelik Bağdâdî’nin verdiği yukardaki bilgi, Nazzâm'ın Seneviyyecileri ve Brahmanları eleştiri mahiyetinde eserler yazmış olmasıyla da çelişmekte ve dayanaksız kalmaktadır (İ. Çelebi, 2006).

Yukarıda değinildiği üzere "Zenâdikadan olan iki rahibin kıssası" başlığı ile Câhız, eserinde bir bölüm 
ayırmıştır. Rahiplerin ibadet amacıyla arzda seyahat ettiklerinden, ikişer kişi olarak gezdiklerinden, bir menzilde iki gece kalmadıklarından, sıdk-tuhur-kuds-miskene yani yalan söylememe, cinselliği terk ile manevi temizlik, sorulsa bile günahlarını gizleme, yaratıcının rızka sebep kıldığı başkalarına kendisinin her an bağımlı olduğunu düşünerek nefis terbiyesi için yemeğini başkasının kazancından yeme gibi ilkelerinin bulunduğundan bahsedilmektedir. Eserin orijinal metninde geçen "en-Nestûri" (النسطوري) ve "el-Melkânî" (الملكاني) kelimeleri ile Hristiyan Nestûri rahiplerine, Rum diyarında "Melkâ/Melkân" beldesinde zuhur eden Melkâniyye'ye mensup Hristiyan Nasarâ'nın en eski gruplarından olan rahiplere değinildiği eserin tahkikli neşrindeki dipnotta kaynaklarıyla anlatılır (Câhız, 1385, s. 4/457-460). Ancak Budist ve Maniheist rahiplerden bahsedilmez. Kaynak eserde verilen sadece bahse konu bilgiden hareketle inancı zayıf bazı ibâhî gruplardan bir çeşit toplum dışı (marjinal) bir zümre oluşabilmesi için söz konusu gezgin rahipleri, Kalenderî dervişlerin kendilerine örnek almalarını doğrulayacak yeterli delil bulunmamaktadır. Başka bir ifadeyle Müslümanların yaşam alanlarını tanıyıp yandaş kazanmak için gezen ve hangi dine mensup olduğu tartışmalı olan rahiplerin hayat tarzından bazı Müslümanların etkilenmesiyle sapkın veya Heterodoksî Batınî Kalenderî bazı dervişlerin İslam coğrafyasında türemiş olabileceği tezinin, İslam tasavvufunda Hint tesirini göstermesi için yeterli kaynağa sahip olmadığı görülmektedir. Ocak, bahse konu iki grup arasında zihniyet olarak değil, giyim kuşam bakımından bir benzerlik olduğunu savunmaktadır (Ocak, 1999, s. 8). Anlaş1lan o ki Ocak, Kalenderîlerden hareketle Kazvînî’nin eserini referans göstererek Goldziher'in İslam Tasavvufunun kaynağının Hint kültürünün tesiriyle oluştuğu görüşüne katılmaktadır.

Kalenderî dervişlerin Budist rahipleri taklit etmiş olabileceklerine dair Goldziher'in tahmininin Ahmet Yaşar Ocak, Müslüman olmayanların bulunduğu şartlar altında da gerçekleştiğini belirtir. Hatta Şakîk menkıbesine telmihte bulunarak bu defa Müslüman topraklarına gelen rahipler değil, Hindistan topraklarına giderek oralardaki Budist rahiplerin yaşantısını yakından inceleyen ve onlarla konuşan sûfîler olduğunu vurgular. Kuşeyrî’nin de aynı nakilde bulunduğunu belirtip İlhanlı tarihçisi Kazvinî’nin naklinin yani yukarıda bahsedilen Şakîk-i Belhî menkıbesinin Budist ve Maniheist rahiplerin İslam tasavvufunun herhangi bir oluşum sürecine katkıda bulundukları tezine destek niteliğinde olduğu kanaatini belirtir (Ocak, 1999, ss. 7-8). Ancak Kazvînî'nin orijinal eserine baktığımızda Şakîk ile ilgili anlattığı olay üzerine Ocak'ın belirttiği gibi bir niyet okuma ve yorum yapılmadığı görülmektedir. Kendisinden önce yazılan Kuşeyrî'nin er-Risâle'sindeki ve daha da öncesinde yazılan Isfahânî'nin Hilyetü'l-evliyâ'sındaki menkıbede geçen "Türk beldesi" yerine Kazvinî'nin belde adı olarak yanlışlıkla "Hind beldesi" ilavesiyle naklettiği görülmektedir (Kazvînî, t.y., s. 333). Zira Kazvinî’ den önce yazılan iki eser de "Türk beldesi” konusunda birbiriyle tutarlıdır. O halde Şakîk'in yaşadığı dönemde her ne kadar az sayıda Türklerin ikamet ettiği yerler olsa da ülke genelinde Hindistan, Hint bölgesel krallıkları tarafından yönetilmekteydi. Kazvinî’nin yaşadığı dönemde ise Delhi Türk Sultanları yönetimi Hindistan'da egemen güçtü (Özcan, 1998, ss. 80-81). O yüzden Isfahânî ve Kuşeyrî'nin anlattığı Şakîk menkıbesinin Hindistan'da değil, tarihi Türkistan bölgesinde geçtiği değerlendirilmektedir (Bolat, 2010, s. 305). Tarihi Türkistan diye bilinen bölge, güney sınırı olarak Afganistan'da Türkler'in yaşadığı Mezar-1 şerif (Belh) ve Bedahşan ile İran'ın kuzeydoğusunda Horasan vilâyetindeki Türkmenlerin bulunduğu yerin kuzeyini ve doğusunu, Ural dağları ve Volga 1rmağından Hazar denizinin kuzeyindeki ve Mâverâünnehir'in doğusundaki dağları, Çin Sincan Uygur bölgesi de dahil Moğolistan, Güney Sibirya, Türkmenistan, Özbekistan, Kazakistan, Kırgızistan, Tacikistan gibi ülkeleri içine alan geniş coğrafyadır (Taşağıl, 2012, s. 41/556). Bu bölgede de İslam öncesinde Hinduizm dininin mistik boyutunu yaşamaya çalışan ve erkek için "sadhu/sadu" bayan için "sadvi" veya "aryike" adıyla tanınan az sayıda mistik bulunmaktaydı. Sadu, Sanskritçe bir kelimedir. Bu kelime "doğru", "saf", "kutsal" anlamlarına gelir. Modern Hindistan'da sadu kelimesinin eş anlamlısı olarak "hazret, dince saygı değer olan", "Hindu azizi", "azizlere benzeyen" 
anlamlarının karşılığı olan sözcüklerin anlamında yaygın olarak kullanılır. Hint dilinde "sadu"nun sonundaki "u" harfi bazen düşürülür ve sonuçta ortaya çıkan "sadıh" sözcügü yaygın olarak kullanılmaktadır. Sadu kelimesi ikinci anlam olarak, belirli bir tarikatı ifade etmek için de kullanılmıştır. Saduların bazıları, toplum tarafindan saygınlığı olan ve ruhani güçleri bulunan istidrac (olağanüstü ruhani güç) sahibi kişilerdi. Bu topluluğa mensup olanlar genellikle uzun saçlı ve uzun bıyıklı olurlar. Çizgisiz düz beyaz renkte, bazen Budist rahiplerin giysilerinin rengine benzeyen portakal renginde veya safran renginde elbiseler içinde, Tanrı Şiva'nın sembolü alınlarına boyanmış halde gezerler (Ayrıntı için bakılabilir: (De Coster, 2017, s. 143; Garbe, 1918, ss. 831-833; Grierson, 1918, s. 48)). Bazen Brahman asetikler olan (asetik konusunda ayrıntı için bakılabilir: Melchert, 2006, ss. 71-72) yogiler ile sadular birbirine karıştırılmaktadır. "Her sadu, bir yogidir. Ancak her yoga yapan yogi, bir sadu değildir" denilir. Yoga, Brahmanizm felsefesinin altı sisteminden birisidir. Genelde garip takıları olan dilenci görünümlü bu mistik sadu grubunun içerisine, yüz yıllar süren uzun zamanlar boyunca yüzlerce kaçak suçluların gizlenmek için karıştığı, saduların hayat tarzına göre yaşıyormuş gibi gözüktükleri, firsatını bulduklarında gizli kalmasına dikkat ederek başka suçları işlemeye devam ettikleri, böylece pek çok masum gezginin bu mistik sadu görünümündeki kaçakların kurbanı konumuna düştükleri nakledilmektedir (Ayrıntı için bakılabilir: (De Coster, 2017, s. 143; Garbe, 1918, ss. 831-833; Grierson, 1918, s. 48)). Örnek verilen sahte sadular gibi sapkın ve sözde derviş Kalenderîlerden bir kısmının da gizlenmek için asıl Kalenderî dervişler arasına karışan kaçak suçlular olabilir.

Yukarıda menkıbesi değerlendirilen Şakîk-i Belhî’nin, kaynaklarda yer alan bilgilere göre (diğer kaynaklar için bakılabilir: Bolat, 2010, ss. 305-306 Dipnot 22) yaşadığı dönemde, Ebu Hanife'nin (ö. 150/767) ilmî alt yapısını oluşturduğu anlayışı (Uzunpostalcı, 1994, s. 10/131) saymazsak, bugünkü anlamda Matüridîlik ve Eş`arîlik şeklinde iki kolla temsil edilen Sünnîlik henüz sistemleşmemişti. Ancak Şakîk'in İslami yaşantısının, Hz. Peygamber döneminde sahabelerin de yaşadığı bilinen geleneksel Sünnî (Ortodoks) ${ }^{5}$ inançtan olup Heterodoks (gayr-i Sünnî) inanç ve ahlaki yaşam tarzının dışında kaldığı anlaşılmaktadır. Ayrıca zamanla İslam coğrafyasında Budist rahiplere benzeyen Kalenderî dervişlerin yayılmasıyla Hint mistisizminin İslam tasavvufunu etkilediği görüşüne destek niteliğinde anlatılan söz konusu menkıbenin, bahse konu iddiaya örnek teşkil etmeyeceği belirgin bir şekilde ortadadır.

Zihniyet olarak değil, kulağı küpeli Türkmenlerle, Şiî olan kimi insanların küpe takma gibi sırf ortak giysilerden hareketle Babinger ve Köprülü'nün, Budist veya Hindu yogi ve sadular ile bazı Şiî inancına mensup kişilerin birbirlerinden etkilenmiş olabilecekleri varsayımları (Babinger ve Köprülü, 1996, ss. 80, 118), İslam'da Hint mistik etkisinin varlığını savunan oryantalistlerin tesirinde kalma olarak açıklanabilir. Çünkü daha sonra Şîi inancına mensup olanlar, içerisinde yer alsa da Cevlekıyye/Kalenderiyye tarikatını Hindistan'a ilk getiren kişinin, Sühreverdiyye tarikatı şeyhi Bahaeddin Zekeriya Multânî’nin bir zamanlar müridi olan ve "La'1 Şahbaz Kalender" (لعل شهباز قلندر) diye tanınan İran Merendli Seyyid Muhammed Osman Merendî (ö. 537/1274) olduğu bazı eserlerde geçmektedir (Lâhûrî, 2001, s. 2/172-175; Perviz, 2009, ss. 370-374). Osman Merendî’nin Sünnî Sühreverdiyye tarikatının mensubu iken Kalenderîliği de Hindistan'da yaymaya çalışması dikkat çekici bir konudur. Yani Hint yogi ve sadularından etkilenmeyen ve Hindistan'da önceden olmayan Haydârîlik ve Kalenderîlik oraya ülke dışından gelmiştir. Eğer İslam ve Hint kültürü arasında Ocak, Babinger ve Köprülü’nün bahsettiği konuda ve boyutta bir etkileşim olsaydı bunun en elverişli ve en öncelikli yeri Hindistan olmalıyd.

Yine bazı kaynaklarda miladi on üç ve on dördüncü yüzyıllarda Hindistan'daki Kalenderiyye tarikatının Anadolu'dan beslendiği yönünde de bilgi bulunmaktadır. Şöyle ki; Hint diyarının meşhur

\footnotetext{
${ }^{5}$ Buradaki "Ortodoks" ifadesi, "Heterodoks" kavramının karşıtı olarak kullanılmaktadır.
} 
şeyhlerinden birisi olan ve Delhi'de doğan, doğum-ölüm tarihi tam tespit edilemeyen Necmeddin b. Nizameddin el-Gaznevî ed-Dehlevî, Çiştiyye tarikatı şeyhlerinden Nizameddin Muhammed elBedâyûnî’ye (ö. 725/1325) intisap eder. Bir müddet seyr ü sülûke devam eder. Ancak keşif ve müşahede kapıları ona açılmaz. Şeyhinin emriyle Rum diyarına (Anadolu'ya) gönderilir. Anadolu'da Şeyh Hızır el-Hüseynî el-Kalender er-Rûmî’nin sohbetlerinde bulunur; manevi eğitimini tamamlar ve ondan Kalenderiyye tarikatı yetkisini alır. Maksat hasıl olduktan sonra Hindistan'a geri döner. Mandu'da ikamet eder. Orada Şeyh Hüseyin es-Serherpûrî, Şeyh Kutbeddin el-Civanpûrî ve diğerleri Kalenderîliği yaymak için ondan yetki alırlar (Hasenî, 1962, s. 3/283). Yani Seyyid Hızır er-Rûmî Kalenderiyye tarikatının önemli büyüklerindendir. Ömrü seyahatle geçmiştir. Kalenderiyye tarikatını Şeyh Abdülaziz Abdullah Âlemberdâr el-Mekkî'den almıştır. Şeyh Hızır, seyahatlerinin birisinde Hindistan'a gider. Delhi'de Şeyh Kutbeddin Bahtiyar Kâkî'den de (ö. 633/1235) Çiştiyye tarikatı hırkasını giyer. Sonra oradan ayrılıp seyahatlerine devam eder. Şeyh Hızır Kalender'in Gavsiyye adlı eserine göre uzun seyahatlerin ardından Hindistan'a ikinci kez gittiği ve orada vefat ettiği nakledilir. Âlemberdâr, uzun ömrü olan ve olağanüstü bir yaşantısı bulunan efsanevi bir şahsiyettir (Hasenî, 1962, s. 1/105). Ahmet Karamustafa ise, "Şeyh Hızır-1 Rûmî herhalde anayurdu Anadolu'da öldü” ifadesini kullanır (Karamustafa, 1994, s. 59, 2016, s. 74).

\section{Bîrûnî’nin Bazı Görüșlerinin İslam'da Hint Tesirine Delil Gösterilmesi}

Hindistan'1 gezip eser yazan Ebu Reyhan Muhammed el-Bîrûnî, Hindu öğretilerinin hurafelerle dolu olduğunu, melekler olarak algıladığı "deyve/deva" (ديو) sınıfı hakkında Hint kitaplarında akıl almaz ve tuhaf hikayeler bulunduğunu, bu sözlerin meleklere tanrılar diyen Yunanlıların sözlerine benzediğini, İslam kelamcılarının meleklere atfedilen bu niteliklerin meleklerin doğası ve şerefleriyle uzlaşmadığı görüşünü (Bîrûnî, 1983, s. 67, 2015, s. 55) naklederek Hindu inancının, İslam inancından uzak olduğunu beyan etmektedir. Ancak Bîrûnî, inancın dışında Hakk'ı tefekkürle meşgul olma konusunda İslam sûfîlerinin Patanjali'nin ${ }^{6}$ görüşüne (Ayrıntı için bakılabilir: A. Jones ve D. Ryan, 2007, s. 327) yakın olduğunu belirtir. Hilmi Ziya Ülken'e göre Bîrûnî’nin bu iddiası çok şüphe götürür. Çünkü Müslümanlar Hindistan'a öncelikle harp yoluyla değil, mutasavvıflar yoluyla girmişlerdir ki İslam tarikatlarının tesiri, Hind'in sistemleşmemiş şekilsiz mistisizmini Patanjali doktrini denilen sistematik felsefi mistisizm haline getirmiştir. Hatta daha sonraki zaman diliminde yetişen Gandhi'nin, Satyayroha (ilahi aşk) doktrini İslam tasavvufunun tesiriyle vücuda gelmiştir, Hint mistisizminin tesiriyle değil (Ülken, 1995, ss. 89-90).

Bîrûnî'nin büyük mutasavvıf Ebu'l-Fetih el-Bustî’nin tesiri altında olduğu bu nedenle tasavvufa karş1 olmadığ1, "sûfı̂" kelimesinin kökeniyle ilgili araştırmalarının, tasavvuf felsefesiyle ilgili karşılaştırmalarının, tasavvufî hareketlerin hepsini objektif ilmî esaslar çerçevesinde inceleme yaptığı, Bîrûnî’nin Kitabü'l-Cemâhir adlı eserinde zühd ve takva ile ilgili önemli bölümlerin mevcut olduğu, sûfîlerin Hint tesirinde kaldığı görüşünü Browne'nin Bîrûnî’ye atfetmesinin doğru olmadığ1 konularında Günay Tümer'in tespitlerini de burada nakletmekte fayda var (Tümer, 1991, ss. 217-218 (Dipnot 322)).

İslam tasavvufu, asırlarca Hindistan'ı yöneten Delhi Türk Sultanlığı'nın genelde her döneminde (588932/1192-1526) kuvvetli idi. Hindistan'da bu akım Hint düşüncesini değiştirecek kadar etkili olmuştur. Eski canlılığını kaybederek şekilciliğe boğulmuş Brahmanizm'e karşı içten ve gerçek ibadete üstünlük veren Bakhti hareketinin 14. asırdaki kuvvetli savunucusu Ramanand'ın şu düşünceleri İslam tasavvuf inancının kültürel etkinliğini yansıtmaktadır: "Her şeye hâkim olan Allah'1n kudreti, her şeyde mevcuttur" (Rizvi, 1986, s. 1/373-384).

\footnotetext{
${ }^{6}$ Patanjali, milattan önce iki yüz (200) yılı civarında yaşamış Yoga Sutra yazarıdır.
} 
İslam Tasavvufunun Hint kaynaklı yabancı tesirlerden etkilenerek şekillendiği ile ilişkili söz konusu iddiaların bir kısmına destek veren Afífî, aynı eserinde tarihi açıdan İslam tasavvufunun bir ilim olarak ortaya çıkmasından önce Müslümanlarla Hindular arasında ilmî bir bağlantı olduğunu teyit edecek bir delilin bulunmadığını söyler. Ayrıca Afîfî, tasavvuf ilmi kemale ermeden önce Hindistan ile alakalı Arapça bir eser de yazılmadığını belirtir. Afîfî, türünün ilk örneği olan Bîrûnî’nin eserlerinin, tasavvufun dini ilimler arasında ayrı bir ilim dalı olarak ortaya çıkışından oldukça uzun bir süre sonra yazıldığına dikkat çekmektedir. Ancak bu durumun bazı Hint kökenli fikirlerin sonraki devir sûfîlerine hiçbir etkisi olmadığı anlamına gelmeyeceğini savunan Von Cramer'in görüşüne katılmasını etkilemediğini de belirtir (Afîfî, t.y., s. 58). Mahmud Erol Kılıç da R. C. Zaehner'in Hint kültüründeki bazı temaların İslam tasavvufuyla ve İbnü'l-Arabi'nin sistemiyle benzeştiğini savunduğu görüşlerinin çok zorlama olduğunu belirtmesi (K1lıç, 2011, s. 105 (Dipnot 2)) önem arz etmektedir. Yani her sistem kendi içerisinde nev'i şahsına münhasır olarak değerlendirilmelidir.

\section{Değerlendirme ve Sonuç}

Yukarıda verilen bulgu ve bilgiler 1şı̆̆ında yapılan tartışmaların sonucu olarak Hint mistisizminin İslam tasavvufuna etki ettiğine dair iddialar, kimi oryantalistlerce bazı ilmî verilere dayandırılmaya çalışılmış olsa da Annemarie Schimmel gibi bazı tasavvuf araştırmacıları tarafindan da tutarlılığı, geçerliliği ve gerçekliğinin bulunmadığı nedeniyle kabul görmemiştir. Varılan bu yargıyı destekleyici olarak Hodgson ve Hilmi Ziya Ülken gibi bilim insanları özellikle Doğu'da İslam'ın yayılışının Hint kültüründeki etkisinin Avrupa kültüründeki etkisinden daha kesin bir şekilde belirleyici olduğunu değerlendirmeleri önem arz etmektedir. İslam medeniyeti ve kültürünün Hint medeniyetinden etkilenmediğine, tam tersine İslam kültürünün tüm çağlarda Hint kültürünü etkileyecek kadar kuvvetli olmasina da vurgu yapılmaktadır.

İlim dünyasında kabul gören yukarıdaki anlayışın aksi iddialar, günümüze kadar oluşan genel kanaatten, çok daha önce sistematik bir şekilde tarihte ilk kez İngiliz oryantalist Sir William Jones'un öncülüğünü yaptığı çalışmalarla ortaya konulup başkaları tarafindan devam ettirilmiştir. O yüzden bu iddiaların, oryantalizmin siyasi amaçlarına hizmet etme gayesine matuf çalışmaların ürünü olduğu, ilmî gibi görünen verilerin siyasi bir arka planının bulunduğu anlaşılmaktadır. Bahse konu iddiaların aslının içeriğine, çeşitli araştırma ve incelemeler neticesinde pek çok kaynaklardan ve görüşlerden yararlanılarak belirginlik kazandırılmaya çalışılmıştır. Gerek Hindistan gerekse dünyanın diğer herhangi bir coğrafyasında İslam tasavvufunun, özellikle Müslüman devlet yönetiminin egemenliği altında bulunan bir başka kültürü etkileyecek yeterlilik düzeyinde olduğu, yukarıda ayrıntılı olarak verilen "Hindistan'da gayet meşhur bir hikâye" gibi tarihi bilgilerden anlaşılmaktadır. Bu bağlamda oryantalistlerin söz konusu iddialarını doğrular nitelikte İslam'ın değerleriyle bağdaşmayan veya İslam'ın ruhuna aykırı olan genel tasavvufî uygulamalara ve Müslüman toplumların yaşadığı coğrafyalarda yabancı kaynaklı olumsuz etkilenmelere, incelenen kaynaklarda rastlanılmamıştır. Hint mistikleri olan yogi ve saduların yaşam tarzına benzer şekilde hayatını sürdüren Müslüman toplumlarda Cevlekî tarzda kalender meşrep oldukları bilinen kimi bireyler veya küçük grupların Hint mistik felsefesini tanıma ve yaşatma bilincinde olmadıkları, bunların bir kısmının meczub, bir kısmının melâmî anlayışa benzer olumlu Kalenderîler, diğer bir kısmının ise ibâhî yaşam tarzını tercih eden bireyler olduğu görülmektedir. İbâhî anlayışta olanların da ahlaki veya gayr-i ahlaki yaşam tarzını benimseyen farklı küçük gruplar olarak varlığının yanı sıra hiçbir kural tanımayan kanun kaçaklarının da bu gruplar içerisinde gizlenerek yer aldıkları değerlendirilmektedir. Ayrıca inanç sistemlerinin birbirine benzerliğinden hareketle karşılıklı etkilenme iddiaları yerine, evrensel ortak değerler göz ardı edilmeksizin, her sistemin kendi içerisinde nev'i şahsına münhasır olarak değerlendirilmesinin gerekliliği belirgin bir şekilde görülmektedir.

$\mathrm{Bu}$ bağlamda aşağıda belirlenen öneriler ön plana çıkmaktadır: Günümüzde var olan ancak asr-1 
saadette zühd hayatı şeklinde mevcut olmasına rağmen o dönemde ismi bugünkü kullanımıyla konulmamış tasavvuf ilmi gibi bazı İslami ilimler de İslam kaynaklarından doğmuş olup menşei Kur'an ve sünnettir. Çünkü İslam kültürünün dayandığı naslar pek çok kaynağı besleyecek yeterliliğe ve imkâna sahiptir. İslam medeniyetinin kültürel zenginliği, yabancı kaynaklara muhtaç olmayacak kadar yetkindir. Bu nedenle İslam tasavvufu da Kur'an ve sünnette var olan zühd ve nefis mücahedesi anlayışıyla ortaya çıkmıştır. İslam tasavvufundaki bazı uygulamaların yabancı mistik anlayışlarla benzerliklere sahip olduğu görüşü ise, ilk önce Mesûdî, Bîrûnî, İbn Teymiyye ve taraftarları gibi kimi İslam âlimlerince ortaya atılmıştır. Riyazet esnasında az yeme, az uyuma, az konuşma gibi uygulamaların genel kural olarak İslam tasavvufunda olduğu gibi diğer mistik anlayışlarda da ortak olarak bulunması bireyin bu âleme ait olanla bağını zayıflatma amacına yönelik olarak yapılan işin tabiatında bulunduğundan evrensel insani ortak değerdir. Buna göre kimi İslam alimlerince öne sürülen bazı tasavvufî uygulama ve kavramlar ile diğer dinlerdeki mistik kavramlar arasında benzerlik olduğu iddiaları, taassup sahibi bazı oryantalistlerce istismar edilerek geliştirilmeye çalışılmıştır. İslami kaynaklarda yer alan bahse konu haksız eleştirilerin ve iddiaların gelecekte İslam toplumu üzerinde ortaya çıkacak bazı olumsuz sonuçlarının ön görülemediği anlaşılmıştır. Söz konusu argümanların, Müslüman âlimlerce kasıtlı olmaksızın üretildiği değerlendirilmektedir. Bu bağlamda İslam tasavvufunun yabancı kaynaklı olduğu iddiasının zararlarının ve varsa faydalarının kimlere özgü ve neler olduğu karşılaştırmalı olarak olumsuz görüş sahiplerince tekrar değerlendirilmelidir. Bu anlayışla çeşitli ilmî disiplinlerce İslami kaynakların analiz ve sentezleri ilmî uzlaşı içerisinde yeniden yapılandırılmalıdır.

Ayrıca İslam ülkelerinin dışında yapılan ve insanlık tarihi boyunca aktarılarak gelen insanlığın kültürel mirası tarzındaki ilmî çalışmalardan yararlanılıp İslami ilimlerde söz konusu verilerin kullanılmasının dince bir sakıncası yoktur. İslam'ın naslarıyla çelişmeyen bahse konu verilerin, Müslüman toplulukların faydasına olacak şekilde İslami ilimlerde kullanılması, eleştiri konusu edilmemelidir. İslam dışı kaynaklardan beslenildiği iddialarıyla bazı Müslümanları ötekileştirme ve yabancı unsurların iş birlikçisi olarak tanımlama, zanna dayalı suçlama olduğundan İslam'ın genel ilkelerinin özüyle çeliştiği için toplumun vicdanında kabul görmemektedir. İlmî olan hiçbir görüş, akım veya felsefi anlayışa karşı ön yargılı olma, ilmî verilere dayanmayan ötekileştirici yaklaşım tarzını ve tutumunu devam ettirme hem insani hem de bilimsel değildir. Ayrıca Müslüman toplumların iyi yönetimi ve huzuru için dini konular siyasetle ilişkilendirilebilir. Ancak Ekber Şah olumsuz örneğinde olduğu üzere farklı dinler söz konusu olsa bile din ve vicdan hürriyetini kapsayan konular siyasi çıkar amaciyla siyasete alet edilmemelidir.

\section{Kaynakça}

A. Jones, C. ve D. Ryan, J. (2007). Encyclopedia of Hinduism. New York: Facts on File Publisher.

Afîfî, E.-A. (1996). Tasavvuf: İslam'da Manevi Devrim. (H. İ. Kaçar ve M. Sülün, Çev.). İstanbul: Risale Basin-Yayın.

Afîfî, E.-A. (t.y.). et-Tasavvuf: Es-Sevretü'r-rûhiyye fi'l-İslâm. Beyrut: Dârü'ş-Şa'b.

Ahmed, A. (1964). Studies in Islamic Culture in the Indian Environment. Oxford: Oxford University Press.

Ahmed, A. (2001). Şah Veliyyullah Dehlevî’nin Dini ve Siyasi Görüşleri. Journal Of Islamic Research, 14(3-4), 536-541.

Akdağ, E. (2019). Sûfîlere İsim Arayışları ve Tasavvuf Kelimesinin Menşei Meselesi. Cumhuriyet Ilahiyat Dergisi, 23(2), 715-737.

Akdağ, E. (2020). Hallâc'ın Mahkeme Süreci ve Katline Fetvâ Verenler. Din Bilimleri Akademik Araştırma Dergisi, 20(2), 1167-1194. 
Algar, H. (1996). Gucdüvânî Abdülhâlık. İstanbul: Türkiye Diyanet Vakfı Yayınları.

Ateş, S. (t.y.). Cüneyd-i Bağdâdî: Hayatı, Eserleri ve Mektuplart. İstanbul: Yeni Ufuklar Neşriyat.

Attâr, F. (1387). Tezkiretü'l-Evliyâ. Tahran: Gencîne.

Attâr, F. (2012). Evliyâ Tezkireleri. (S. Uludağ, Çev.). İstanbul: Kabalcı Yayıncılık.

Attar, S. F. (1905). The Tadhkiratu'l-Awliya. Leiden: Brill.

Azamat, N. (1992). Bülbül Şah. Türkiye Diyanet Vakfı İslam Ansiklopedisi. İstanbul: TDV Yayınları.

Babinger, F. ve Köprülü, M. F. (1996). Anadolu'da İslâmiyet. (R. Hulusi, Çev.). İstanbul: İnsan Yayınlar1.

Bayur, Y. H. (1987). Hindistan Tarihi (C. 1-3). Ankara: Türk Tarih Kurumu Basımevi.

Bîrûnî, E. R. M. b. A. (1983). Tahkîku mâ li'l-Hind min makûletin makbûletin fi'l-a 'kl ev merzûle. Beyrut: Âlemü'l-Kütüb.

Bîrûnî, E. R. M. b. A. (2015). Tahkîku mâ li'l-Hind. (K. Burslan, Çev.). Ankara: Türk Tarih Kurumu.

Bolat, A. (2010). Şakîk-i Belhî. Türkiye Diyanet Vakfi Íslam Ansiklopedisi. İstanbul: Türkiye Diyanet Vakfi Yayınları.

Böwering, G. (1989). Bestami, Bayazid. Encyclopaedia Iranica. Leiden: Brill.

Câhız, E. O. A. b. B. el-. (1385). Kitâbü'l-Hayavân (C. 1-8). Kahire: Matbaa Mustafa el-Bâbî elHalebî.

Câmî, E.-B. N. A. b A. b M. (2001). Nefahâtü'l-üns: Evliyâ Menkıbeleri. (L. Çelebi, Çev.). İstanbul: Marifet Yayınlar1.

Carlo, C. (t.y.). Zaehner, Robert Charles. Encyclopaedia Iranica. online edition. 22 Eylül 2015 tarihinde http://www.iranicaonline.org/articles/zaehner-robert adresinden erişildi.

Chand, T. (1936). The Influence of Islam on Indian Culture. Allahabad: The Indian Press.

Çelebi, İ. (2006). Nazzâm. Türkiye Diyanet Vakfi İslam Ansiklopedisi. İstanbul: Türkiye Diyanet Vakfı Yayınları.

Çift, S. (2007a). Tasavvuf Araştırmalarında Alman Ekolü-1: Tarihsel Boyut. Tasavvuf: İlmî ve Akademik Araştırma Dergisi, (18), 178-179.

Çift, S. (2007b). Tasavvuf Araştırmalarında Alman Ekolü-2: Tasavvuf Alanında Çalışma Yapan Alman Oryantalistler ve Eserleri. Tasavvuf: İlmî ve Akademik Araştırma Dergisi, (19), 165186.

De Coster, P. L. (2017). The Himalayan Sadhus. Belgium: Satsang publications.

Derin, S. (2018). İngiliz Oryantalistlerinin Tasavvuf Araştırmalarına Katkıları. Türkiye Araştırmaları Literatür Dergisi, 16(31-32), 177-196.

el-Bağdâdî, A. (1991). el-Fark beyne'l-Firâk: Mezhepler Arasındaki Farklar. (E. R. Fı̆̆lalı, Çev.). Ankara: Türkiye Diyanet Vakfı Yayınları.

el-Herevî, A. el-Ensârî. (1988). Kitabü Menâzili's-Sâirin. Beyrut: Dârü'l-Kütübi'l-İlmiyye.

el-Herevî, A. el-Ensârî. (2008). Menâzilü’s-Sâirîn. (A. Tek, Çev.). Bursa: Emin yayınları.

el-Kâşânî, K. A. b A. (2004). Latâifü'l-i lâm fî işârâti ehli'l-ilhâm: Tasavvuf Sözlügüu. (E. Demirli, Çev.). İstanbul: İz Yayıncılık.

el-Kâşânî, K. A. b A. (2005). Latâifü'l-i 'lâm fỉ işârâti ehli'l-ilhâm. Kahire: Mektebetü's-Sekâfeti'dDîniyye.

el-Yâfiî, E. M. A. A. b. E. el-Yemenî. (1997). Mir'atü'l-cinân ve 'ibratü'l-yakazân fì ma 'rifeti havâdisi'z-zamân (C. 1-4). Beyrut: Daru'l-Kütübi'l-İlmiyye.

el-Hatîb el-Bağdâdî, E. A. b. A. (2002). Târîhu Bağdâd (C. 1-16). Beyrut: Dârü'l-Gurabi'1-İslâmî.

es-Sülemî, A. M. b. E.-H. (2003). Tabakâtu's-Sûfiyye. Beyrut: Daru'l-Kütübi'l-i̇lmiyye.

eş-Şârânî, A. (1997). Et-Tabakâtü'l-Kübrâ. Beyrut: Darü'l-Kütübi'l-İlmiye.

et-Tûsî, E. N. S. (1380). El-Lum`a. Kahire: Dârü'l-Kütübi'l-Hadîse.

ez-Zehebî, Ş. M. b. A. (1985). El-'İber fí haberi men gaber. Beyrut: Dâru'l-Kütübi'l-i̇lmiyye.

ez-Zehebî, Ş. M. b. A. (1996). Siyerü a lâmi’n-nübelâ. (Ş. Arnaût, Ed.) (C. 1-25). Beyrut: 
Müessesetü’r-Risâle.

Garbe, R. (1918). Yoga, Yogis. (J. Hastings, Ed.)Encyclopaedia of Religion And Ethics. Newyork: Charles Scribner's Sons.

Görgün, T. (1996). Goldziher Ignaz. Türkiye Diyanet Vakfi İslam Ansiklopedisi. İstanbul: Türkiye Diyanet Vakfı Yayınları.

Grierson, G. A. (1918). Sadhu. (J. Hastings, Ed.)Encyclopaedia of Religion And Ethics. Newyork: Charles Scribner's Sons.

Güngör, E. (1993). İslam Tasavvufunun Meseleleri. İstanbul: Ötüken Neşriyat.

Hasenî, A. b. F. el-. (1962). El-İ lâm bi'men fî târîhi'l-Hind mine'l-a 'lâm el-müsemmâ bi'Nüzheti'lhavâtır (C. 1-8). Haydarâbâd (Dekken): Matba'atü Meclisi Dâireti'l-Ma'ârifi'l-Osmâniyye.

Hatiboğlu, M. S. (1996). Goldziher Ignaz. Türkiye Diyanet Vakfi İslam Ansiklopedisi. İstanbul: Türkiye Diyanet Vakfı Yayınları.

Hodgson, M. G. S. (1974). The Venture of Islam Conscience and History in a World Civilization (C. 1-3). Chicago: The University of Chicago Press.

Hücvirî, E.-H. D. G. A. b O. b A. el-. (2007). Keşfü'l-Mahcûb. Kahire: Meclisü'l a'lâ es-Sekâfiye.

Hücvirî, E.-H. D. G. A. b O. b A. el-. (2010). Keşfü̉l-Mahcûb: Hakikat Bilgisi. (S. Uludağ, Çev.). İstanbul: Dergâh Yayınları.

Hüseyin Vassaf, O. (2011). Sefine-i Evliyâ (C. 1-5). İstanbul: Kitabevi.

Isfahânî, E. N. A. b. A. el-. (1988). Hilyetü'l-evliyâ ve tabakâtü'l-asfiyâ, (C. 1-10). Beyrut: Dâru'lKütübi'l-İlmiyye.

İbn Hallîkân, E.-A. Ş. A. b. M. (1978). Vefâyâtü'l-a yân ve enbâü ebnâi'z-zamân (C. 1-9). Beyrut: Dâru Sâdır.

İbn Manzûr, M. b. M. (1300). Lisânü'l-Arab (C. 1-15). Beyrut: Dâru Sâdır.

İbn Mulakkîn, S. E. H. Ö. b. A. (1994). Tabakâtü'l-Evliyâ. Kahire: Mektebetü'l-Hancî.

İbnü'l-Cevzî, C. E.-F. A. b. A. (1992). Sıfatü's-safve. Beyrut: Dâru'l-Fikr.

İbnü'n-Nedîm, E.-F. M. b. E. Y. İ. (2009). Kitâbü'l-Fihrist. (Eymen Fuad Seyyid, Ed.) (C. 1-4). Londra: Müessesetü'l-Furkan Li’t-Türâsi'l-İslâmî.

Karamustafa, A. T. (1994). God's Unruly Friends. Salt Lake City: University of Utah Press.

Karamustafa, A. T. (2016). Tanrının Kuraltanımaz Kulları. (R. Sezer, Çev.). İstanbul: Yapı Kredi Yayınları.

Kaya, K. (Çev.). (2014). Upanishad: Upanishadlar. Türkiye İş Bankası Kültür Yayınları.

Kazvînî, E. Y. C. Z. b. M. el-. (t.y.). Âsârü'l-bilâd ve ahbârü'l- 'ibâd. Beyrut: Dârü Sâdr.

Kılıç, M. E. (2011). İbnü'l-Arabi Düşüncesine Giriş: Şeyh-i Ekber. İstanbul: Sufi Kitap.

Konukçu, E. (1994). Ekber Şah. Türkiye Diyanet Vakfi İslam Ansiklopedisi. İstanbul: TDV Yayınları.

Kopf, D. (1969). British Orientalism And The Bengal Renaissance: The Dynamics of Indian Modernization 1773-1835. Calcutta: Firma K. L. Mukhopadhyay.

Kuşeyrî, E.-K. Z. A. b. H. el-. (1991). Tasavvuf İlmine Dair Kuşeyrî Risâlesi. (S. Uludağ, Çev.). İstanbul: Dergâh Yayınları.

Kuşeyrî, A. b. H. en-Nisaburî el-. (2008). Er-Risaletü'l-Kuşeyriyye fi ılmi't-Tasavvuf. Beyrut: elMektebetü'l-Asriyye.

Küçük, O. N. (2012). Kalbin Makamlar1-Letâif. K. Özköse (Ed.), Tasavvuf El Kitabı içinde (ss. 5254). Ankara: Grafiker Yayınları.

Lâhûrî, M. G. S. (2001). Hazinetü'l-Asfiyâ. (P. İ. A. Fârûkî, Çev.) (C. 1-4). Lahor: Mektebe Nebeviyye.

Margoliouth, D. S. (1987). Çiştiye. Milli Ĕgitim Bakanlığı İslam Ansiklopedisi. İstanbul: Milli Eğitim Basımevi.

Massignon, L. (1922). Essai Sur Les Origines du lexique technique de la mystique musulmane. Paris: Paul Geuthner. 
Massignon, M. L. (2006). İslam'ın Mistik Şehidi Hallâc-ı Mansûr'un Çilesi. (İ. Birkan, Çev.). İstanbul: Ardıç Yayınları.

Melchert, C. (2006). Ascetics, Asceticism. (J. W. Meri, Ed.)Medieval Islamic Civilization: An Encyclopedia. Newyork: Routledge.

Müller, M. ve Deussen, P. (Ed.). (2010). Upanişadlar: İnsanlığın İlk Felsefi Metinleri. İstanbul: Okyanus Yayinc1lik.

Nicholson, R. A. (1914). The Mystics of Islam. Londra: G. Bell And Sons Limited.

Nizami, K. A. (1993). Çiştiyye. Türkiye Diyanet Vakfi İslam Ansiklopedisi. İstanbul: Türkiye Diyanet Vakfi Yayınları.

Ocak, A. Y. (1999). Osmanlı Imparatorluğunda Marjinal Sufilik: Kalenderiler (14-17. Yüzyıllar). Ankara: Türk Tarih Kurumu Basımevi.

Öngören, R. (2012). Fenâ-Bekâ. K. Özköse (Ed.), Tasavvuf El Kitabı içinde . Ankara: Grafiker Yayınları.

Özcan, A. (1998). Hindistan. Türkiye Diyanet Vakfi İslâm Ansiklopedisi. İstanbul: TDV Yayınları.

Özköse, K. (2013). Tarîkatlarda Eğitim: Letâif-i Hamse. Somuncu Baba: Aylık İlim Kültür ve Edebiyat Dergisi, 22-24.

Öztürk, Y. N. (1976). Aşk ve Hak Şehidi Hallâc-ı Mansûr ve Eseri. İstanbul: Yeni Boyut Yayınevi.

Perviz, H. (2009). Evliyaullah. Lahor: Ali Meyan Pablikeyşın.

Rizvi, S. A. A. (1986). A History of Sufism in India (Early Sufism And Its History in India to 1600 A.D.). Yeni Delhi: Munshiram Manoharlal Publishers Pvt. Ltd.

Schimmel, A. (1980). Islam in the Indian Subcontinent. Leiden: Brill.

Sunar, C. (1966). Mistisizmin Ana Hatlart. Ankara: Ankara Üniversitesi Basımevi.

Sühreverdî, E. H. Ş. Ö. b. M. (1990). Avârifü'l-ma 'ârif: Tasavvufun Esasları. (H. K. Y1lmaz ve İ. Gündüz, Çev.). İstanbul: Vefa Yayıncılık.

Sühreverdî, E. H. Ş. Ö. b. M. es-. (1999). Avârifü'l-ma 'ârif. Beyrut: Dârü'l-Kütübi'l-İlmiyye.

Taşağıl, A. (2012). Türkistan. Türkiye Diyanet Vakfi İslâm Ansiklopedisi. İstanbul: TDV Yayınları.

Tosun, N. (2015). Bahâeddin Nakşbend Hayatı, Görüşleri, Tarikatı. İstanbul: İnsan Yayınları.

Tümer, G. (1991). Biruni’ye Göre Dinler ve İslam Dini. Ankara: Diyanet İşleri Başkanlığı Yayınları.

Tümer, G. (1992). Budizm. Türkiye Diyanet Vakfi İslâm Ansiklopedisi. İstanbul: TDV Yayınları.

Uzunpostalcı, M. (1994). Ebu Hanife. İstanbul: Türkiye Diyanet Vakfı Yayınları.

Ülken, H. Z. (1995). İslam Düşüncesi: Türk Düşüncesi Tarihi Araştırmalarına Giriş. İstanbul: Ülken Yayınları.

Valmiki (Ed.). (1975). Ramayana: 2500 Yıldı Hafizalarda Yaşayan Eser. (Ö. R. Doğrul, Çev.). İstanbul: Nakışlar Yayınevi.

W. Ernst, C. (2003). The Islamization of Yoga in the Amrtakunda Translations. The Journal of the Royal Asiatic Society (JRAS), 13(2), 199-226.

W. Ernst, C. (2014). Muslim Interpreters of Yoga: Müslüman Yoga Yorumcuları. Mezhep Araştırmaları Dergisi, 7(2), 117-128. http://www.emakalat.com/download/article-file/63796 adresinden erişildi.

Yaman, H. (2013). Tasavvufta Dış Tesir Meselesi. E. Cebecioğlu (Ed.), Tasavvuf Tarihi içinde . Ankara: Ankara Üniversitesi Uzaktan Eğitim Yayınları.

Yaman, H. (2016). İsmi Olmayan Bir Hakikatten Hakikati Olmayan Bir İsme Varan Yolculuk: Oryantalist Çalışmalarda Tasavvufun Menşeine Dair Tartışmalar Üzerine Bir Değerlendirme. Akademiar Dergisi, (1).

Yazıc1, T. (1993). Cemâleddîn-i Sâvî. Türkiye Diyanet Vakfi İslâm Ansiklopedisi. İstanbul: TDV Yayınları.

Zaehner, R. C. (1969). Hindu And Muslim Mysticism. New York: The Athlone Press. 